\title{
Dawn of metazoans: to what extent was this influenced by the onset of "modern-type plate tectonics"?
}

\author{
Umberto G. Cordani ${ }^{1 *}$ (D), Thomas R. Fairchild' (D), Carlos E. Ganade' (D), \\ Marly Babinski' (D), Juliana de Moraes Leme' ${ }^{1}$ D
}

\begin{abstract}
The appearance of complex megascopic multicellular eukaryotes in the Ediacaran occurred just when the dynamics of a cooling Earth allowed establishment of a new style of global tectonics that continues to the present as "modern-type plate tectonics". The advent of this style was first registered in $620 \mathrm{Ma}$-old coesite-bearing Ultra-High Pressure eclogites within the Transbrasiliano-Kandi mega-shear zone along the site of the West Gondwana Orogeny (WGO). These eclogites comprise the oldest evidence of slab-pull deep subduction capable of inducing continental collisions and producing high-relief Himalayan-type mega-mountains. Life, prior to this time, was essentially microscopic. Yet with increasing Neoproterozoic oxygenation and intensified influx of nutrients to Ediacaran oceans, resulting from the erosion of these mountains, complex macroscopic heterotrophic eukaryotes arose and diversified, taking the biosphere to a new evolutionary threshold. The repeated elevation of Himalayan-type mega-mountains ever since then has continued to play a fundamental role in nutrient supply and biosphere evolution. Other authors have alluded to the influence of Gondwana mountain-building upon Ediacaran evolution, however we claim here to have identified when and where it began.
\end{abstract}

KEYWORDS: plate tectonics; mega-mountains; Ediacaran biota.

\section{INTRODUCTION}

If we compare the history of life and the dynamic history of Planet Earth, it was extremely fortunate for the stability of life that despite the planet active dynamics over geologic time, surface temperatures were always sufficiently moderate to maintain liquid water in the oceans and, therefore, sustain the continuous biological evolution since at least early Archean time (Valley et al. 2002, Knoll and Bambach 2000, Knoll and Nowak 2017). The first oceans were accumulated via mantle degassing and/or cometary bombardment much earlier, during the Hadean Eon (Mojzsis et al. 2001). Within this realm, life appeared on Earth at least by about $3.8 \mathrm{Ga}$, the age of supracrustal rocks of southwest Greenland (Mojzsis et al. 1996, McKeegan et al. 2007) bearing biogenic carbon isotopes of graphite, or possibly as early as $4.1 \mathrm{Ga}$, the age of similar evidence more recently reported from a Western Australian zircon grain (Bell et al. 2015, see also Nutman et al. 2016, Dodd et al. 2017). For the following three billion years or so, microorganisms were the only life forms in the primitive oceans, and their fossil evidence attests to a very slow evolutionary rate of morphological change (Schopf 1992). The first organisms were prokaryotes, such as bacteria and archaea, which continue microscopic and morphologically

${ }^{1}$ Universidade de São Paulo - São Paulo (SP), Brazil. E-mails: ucordani@ usp.br, trfairch@usp.br, caegeo@gmail.com, babinski@usp.br, leme@usp.br ${ }^{*}$ Corresponding author.

(C) 2020 The authors. This is an open access article distributed under the terms of the Creative Commons license. simple, yet ubiquitous and extremely important, even today. Later, during Proterozoic time, environmental pressures and opportunities led to evolutionary developments that eventually produced the Eukarya, initially and for a very long time solely microscopic, which have lived side-by side with prokaryotes ever since (Knoll and Bambach 2000).

During a relatively long span of geologic time from mid Neoproterozoic to late Cambrian ( 750-500 Ma), important innovations in the fossil record register the birth and proliferation of more complex macroscopic forms of life, especially in the Ediacaran period (635-541 Ma) (Wood et al. 2019, and references therein), while the geologic record reveals rapid changes in continental configurations related to the Gondwana supercontinent formation, extreme climatic variations, including the most severe glacial episodes in Earth history and the oxygenation of oceans and atmosphere, all of which surely exerted great selection pressures on the evolutionary processes responsible for these innovations (Och and Shields-Zhou 2012, Sperling et al. 2013, Santosh et al. 2014, Planavsky et al. 2015, Spence et al. 2016, and references therein). In the final part of this time-frame, during the Tommotian-Botomian interval (535-513 Ma), the "Cambrian explosion of life" took place, as evidenced by the variety and amount of shells, carapaces, and other fossil remains representing all known modern phyla conserved worldwide in Cambrian strata (Erwin et al. 2011, Cunningham et al. 2017a, Wood et al. 2019, and references therein).

Considering the geodynamic evolution of Earth, the planet started hot (van Hunen and Moyen 2012), and has continuously cooled since then. Plate tectonics is the main mechanism 
by which the planet loses its internal heat, with geologic evidence indicating that it started functioning gradually in Archean times (Cawood et al. 2018). Lithosphere subduction is the plate tectonics hallmark, and Brown (2008), after analysing Earth's metamorphic record over geologic time, was able to define a "Proterozoic plate tectonic regime" characterized by oceanic lithosphere subduction. Continental lithosphere remained stable, however, with large areas of granitic-type crust providing the nuclei of major continental masses and several supercontinents during this period. Meanwhile, as Earth cooled slowly during the Archean and most of the Proterozoic, life remained microscopic, as mentioned earlier.

However, in the Neoproterozoic, important modifications occurred both in the planet dynamics and in the life and biosphere complexities (Brasier and Lindsay 2001, Squire et al. 2006, Meert and Lieberman 2008). Due to continuous heat loss, the Earth cooled to a point in which, relatively quickly, basaltic-type oceanic lithosphere could become negatively buoyant. As a result, basalts could be transformed into even denser eclogites in deep subduction slabs. This greater negative buoyancy led to the "slab-pull type" driving the force and appearance of "modern-type subduction zones" and "subduction-to-collision" orogenic belts that would become widespread in the Phanerozoic (Brown 2008). For the first time in Earth's history, ultra-high pressure (UHP) metamorphic terrains bearing coesite or diamond appeared on Earth, indicating subduction of continental crust to depths greater than $100 \mathrm{~km}$, followed by rapid exhumation (Brown 2008). The oldest UHP eclogites described so far (Caby 1994) are Ediacaran in age as shown by Ganade de Araujo et al. (2014a), who obtained robust $\mathrm{U}-\mathrm{Pb}$ zircon ages of $\mathrm{ca} .610 \mathrm{Ma}$. These authors further demonstrated that these eclogites are located along the Transbrasiliano-Kandi megashear (Cordani et al. 2013), which is a huge tectonic lineament, more than $5,000 \mathrm{~km}$ long, linking South America and Africa, interpreted as the possible site of a collisional suture associated with the West Gondwana orogeny (WGO) that produced Earth's first Himalayan-type mega-mountains.

We suggest that the practically simultaneous appearance of the first very large high-relief mountain chains on the Earth's surface, similar in magnitude to the Himalayas, and the radiation of macroscopic metazoans in the Ediacaran are probably intimately related. As we shall see further on, other authors have alluded to the influence of Gondwana mountain upon Ediacaran evolution, but we claim here to have identified just when and where it began.

\section{GONDWANA AMALGAMATION AND THE FIRST HIMALAYAN-TYPE MOUNTAINS ON EARTH}

The Neoproterozoic (1000-541 Ma) was a time of important modifications on the planet dynamics, including especially the onset of modern-type plate tectonics that prevails until the present. Such a regime is characterized by subduction-to-collision orogenic belts and disappearance of large oceanic domains. The Neoproterozoic hosted a specific and long-term episode involving the planet lithosphere, when continental masses of all sizes underwent an extended fragmentation period and new assembly with the disruption of the supercontinent Rodinia into many fragments, starting around $900 \mathrm{Ma}$, and Gondwana amalgamation that ended around $500 \mathrm{Ma}$. Moreover, at the end of the Neoproterozoic, in the Ediacaran, with Gondwana assembly in full progress, marked changes occurred in relief, climate, oceans and atmosphere, while complex forms of life, including the first macroscopic metazoans appeared, proliferated, and spread quickly over the Earth (Wood et al. 2019).

Rodinia was assembled in the late Mesoproterozoic (Hoffman and Li 2009) by a series of orogenic pulses usually included in the Grenvillian Orogenic Cycle, roughly between 1300 and $1000 \mathrm{Ma}$, the last of which the Rigolet orogeny dated between 1010 and $980 \mathrm{Ma}$ (Rivers 2008, and references therein). Rodinia was a long-lived supercontinent centered around Laurentia and comprised the existing continental masses, which by $1000 \mathrm{Ma}$ ago occupied a significant part of the planet surface. It remained tectonically stable for more than $200 \mathrm{Ma}$, but at ca. $750 \mathrm{Ma}$ a series of breakup events produced rift-related basins, including large passive margins on both sides of Laurentia (Li et al. 2008). Fragmentation terminated around $600 \mathrm{Ma}$ (Trindade et al. 2006), when Laurentia rifted away from Amazonia, thereby opening the Iapetus ocean. By that time, Gondwana had become almost completely assembled out of various cratonic fragments that had previously rifted away from Rodinia.

Gondwana was made up of several older continental masses, such as Amazonia, West Africa, Sahara, São Francisco Congo, Kalahari, Arabia, India, Madagascar, Australia, Antarctica and a few minor fragments, but it remained for a long time independent of Laurentia, Siberia, and China (Fig. 1) (Meert and Lieberman 2008, Merdith et al. 2017). Its amalgamation began about $650 \mathrm{Ma}$ and was complete at ca. $500 \mathrm{Ma}$. About $200 \mathrm{Ma}$ later, the latter three continental masses were reunited with Gondwana to form the Pangea supercontinent. In the transition from Rodinia to Gondwana, two very large oceans were consumed by means of subduction-to-collision roughly between 900 and $500 \mathrm{Ma}$, with closure of the Goiás-Pharusian Ocean in the West, and the Mozambique Ocean in the East. The former is now the WGO (Ganade de Araujo et al.2014b) and the latter is the site of the East African Orogen (EAO).

According to the paleomagnetic interpretations of Meert and Van Der Voo (1997), the Gondwana supercontinent was formed as a succession of three first-order orogenic events that belong to the Brasiliano-Pan-African orogenic cycle, each occupying a specific space and time (Fig. 1). This began with the convergence between the São Francisco-Congo and Amazonia-West Africa-Rio de la Plata cratonic masses that closed the Goiás-Pharusian Ocean (Kröner and Cordani 2003) and produced the WGO (650-600 Ma). The other two orogenic episodes were responsible for the closure of the Mozambique Ocean and, consequently, the formation of the EAO, which is the world's largest Neoproterozoic to Cambrian orogenic complex (Stern 1994). This involved a collision between Congo and India-Madagascar during the EAO (600-550 Ma), followed 
by collision of the rest of Gondwana and Australia-Antarctica in the Kuunga Orogeny (550-500 Ma).

Ganade de Araujo et al. (2014b) have argued that deeply subducted rocks, specifically the eclogites with coesite exposed in the WGO, comprise the earliest evidence of large-scale deep continental subduction on Earth. This linear belt, more than $5,000 \mathrm{~km}$ long and including the oldest known UHP eclogites in the world (Caby 1994, Jahn et al. 2001), cuts across South America and extends into present-day North-West Africa (Fig. 1). It represents a series of sutures associated with final convergence between the conjoined Amazonian and West African cratons, on one side, and the Saharan and Congo-São Francisco cratons, on the other, close to the present site of the Transbrasiliano-Kandi mega-shear zone.

The long-term convergent plate motion and evolution of eastward subduction within the Goiás-Pharusian Ocean started at ca. $900 \mathrm{Ma}$ (Fig. 2). Successive "soft collisions" occurred between about 800 and $650 \mathrm{Ma}$ and culminated in terminal continental collision roughly between 650 and $600 \mathrm{Ma}$ (Ganade de Araujo et al. 2014a, Ganade de Araujo et al. 2014b), when the Pharusian-Araguaia-Paraguay belts were closed. The Goiás magmatic arc is a major area of soft collision and accretion of the Amazonian Craton margin made up essentially by Neoproterozoic granitoids with juvenile signatures that indicate they represent the roots of a series of intra-oceanic island arcs produced by consumption of oceanic lithosphere (Pimentel et al. 2000). The predominantly calc-alkaline chemistry of these magmatic rocks indicates persistent, subduction-related and active margin processes (Ganade de Araujo et al. 2014a).

Along the WGO, ages of UHP coesite-bearing eclogitic rocks marking the suture zones between colliding cratons in Mali, Togo and NE Brazil were obtained by Ganade de Araujo et al. (2014a), using coupled U-Th-Pb and REE zircon

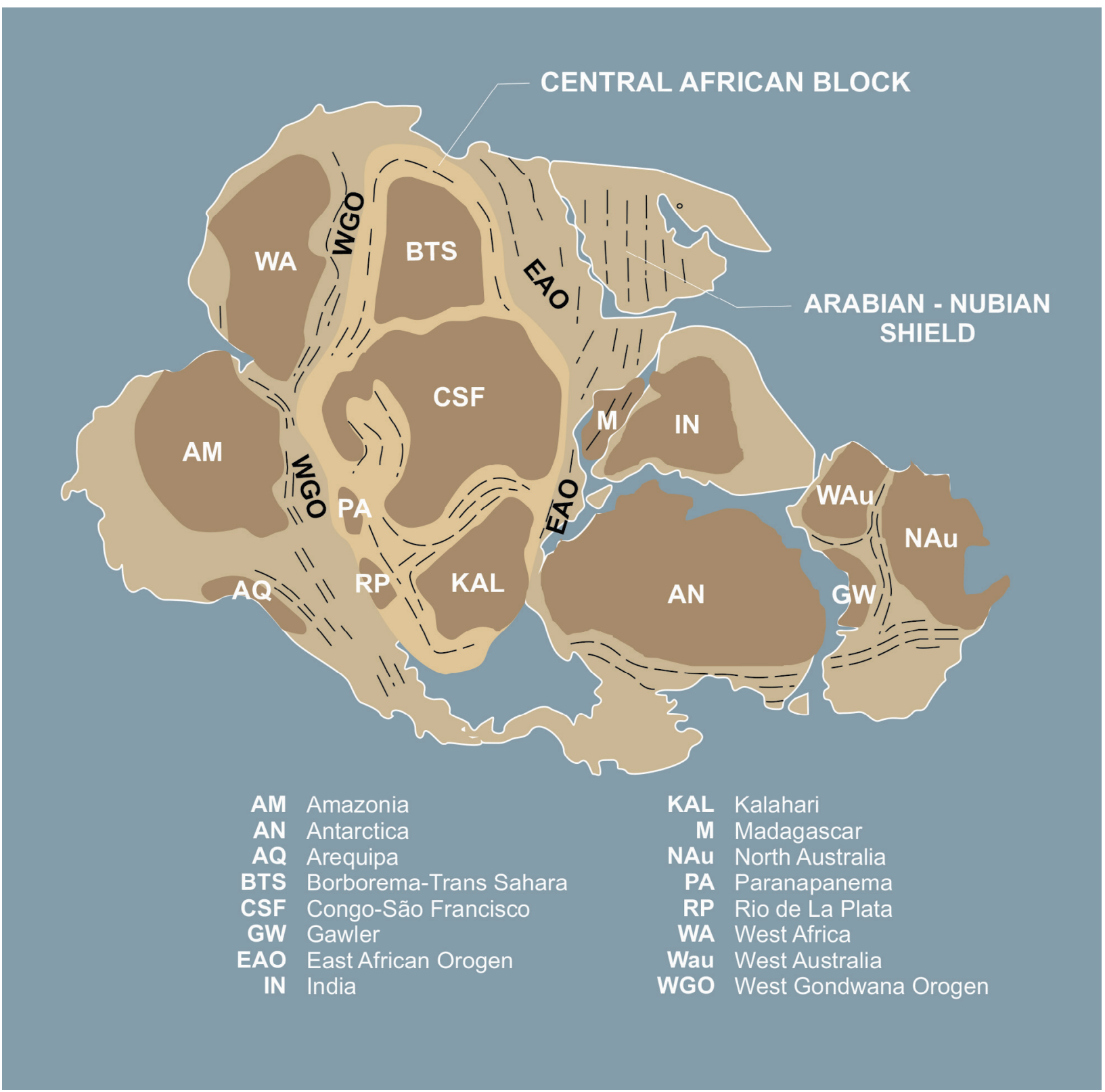

Figure 1. Reconstruction of the former supercontinent Gondwana showing the distribution of ancient cratonic nuclei within modern continents and their position regarding important orogenetic features (broken lines), with emphasis on the West Gondwana (WGO) and East African (EAO) orogens. 
analyses together with geothermal-barometric constraints. The deep continental collision timing was determined from $\mathrm{U}-\mathrm{Pb}$ SHRIMP measurements on overgrowth rims of zircon in the eclogites, as follows: $611.3 \pm 3.6 \mathrm{Ma}$ for Mali, $608.7 \pm$ 5.8 Ma for Togo and 616.0 \pm 4.0 Ma for NE Brazil (Fig. 3). Within experimental error, these results indicate Ediacaran age for the UHP metamorphism and simultaneous subduction of at least three fragments of continental margin along the WGO. Moreover, P-T determinations indicate subduction of this continental margin to depths conducive to UHP metamorphic conditions over a distance of at least $2500 \mathrm{~km}$ within the WGO, which is comparable to the extent of the present

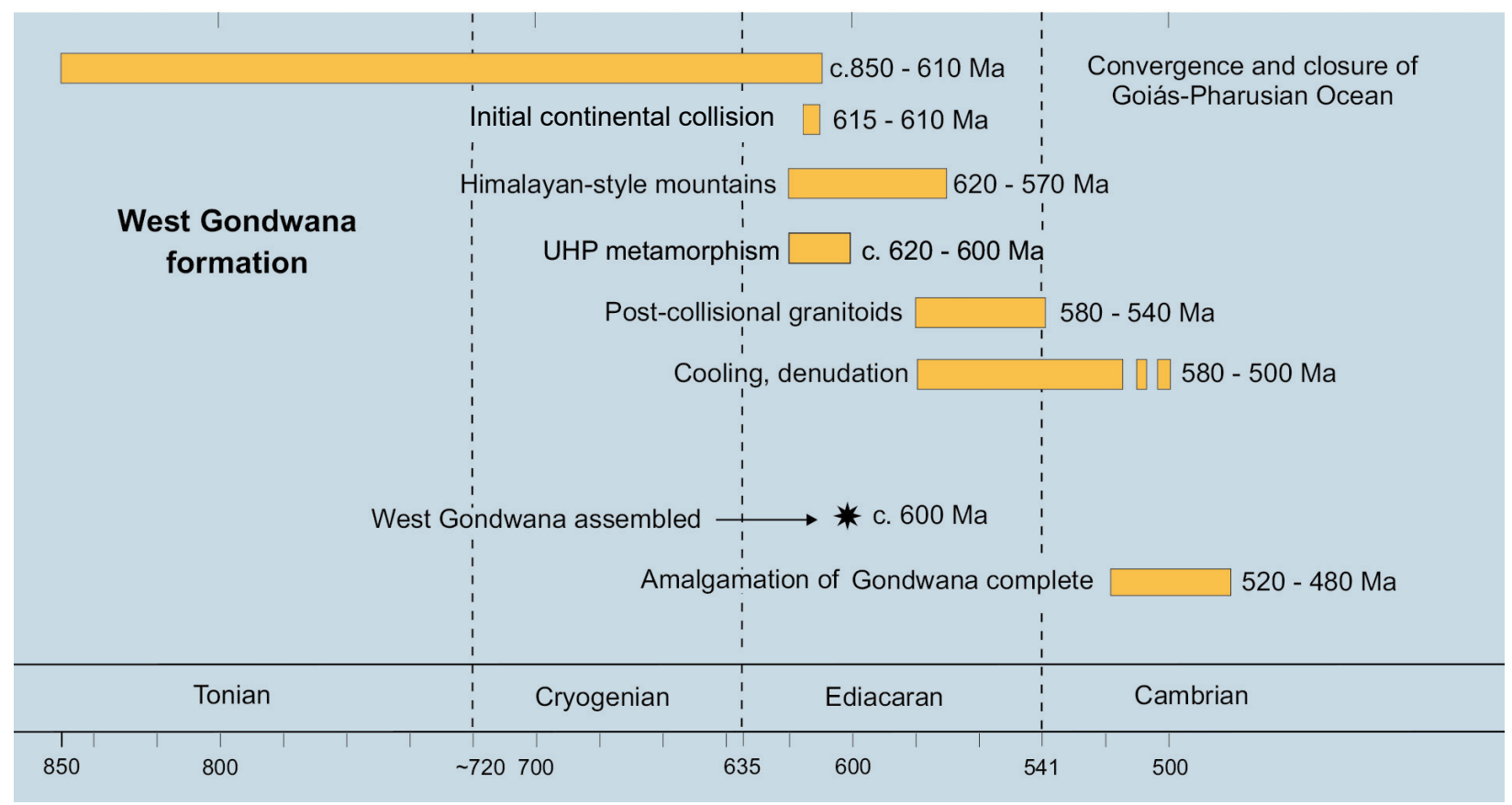

Figure 2. Graphic representation of the history of West Gondwana assembly and the formation and denudation of Earth's oldest known Himalaya-style mega-mountains.

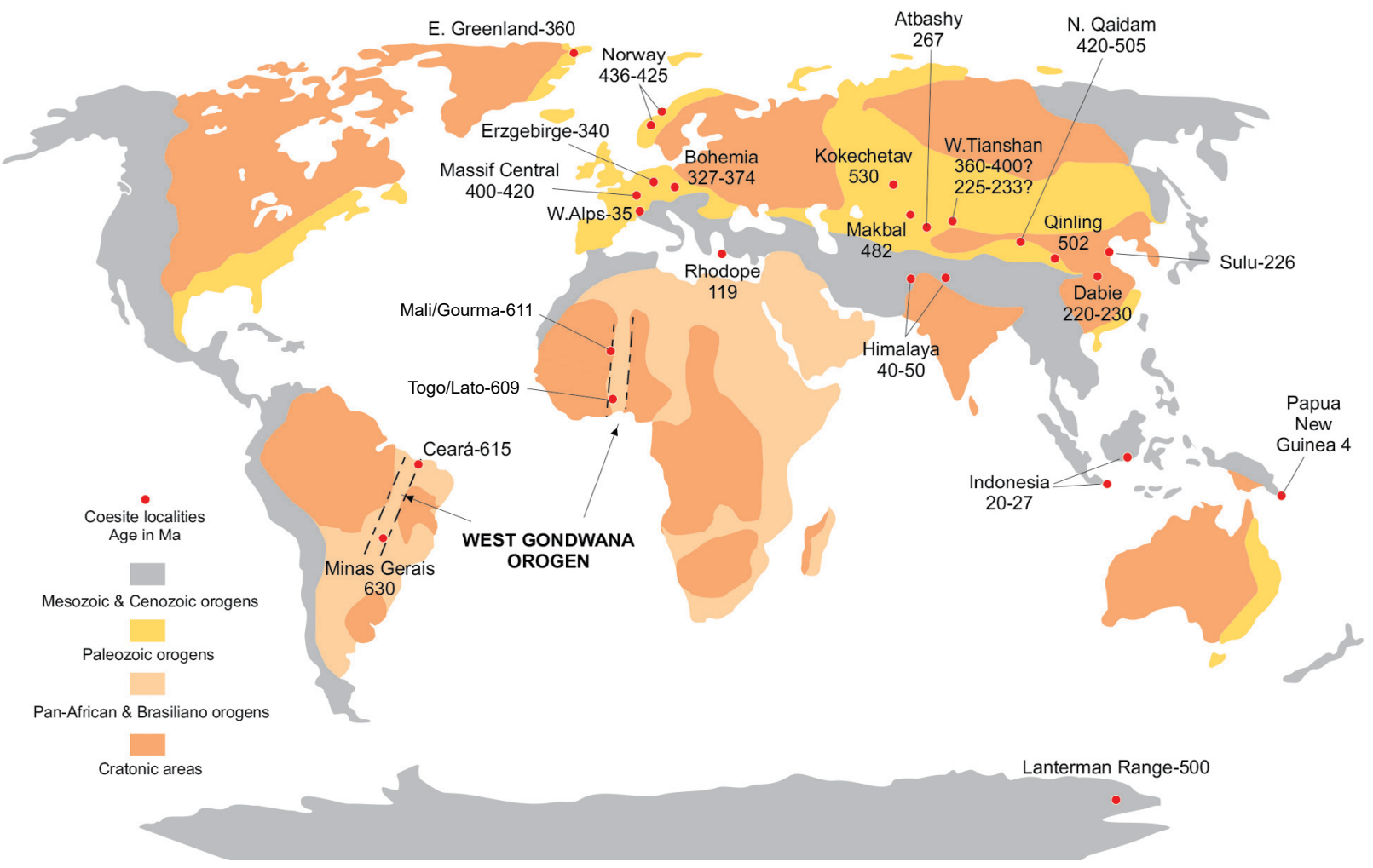

Source: adapted from Tsujimori et al. (2006).

Figure 3. All presently known locations of ultra-high pressure (UHP) terrains exposing eclogites that contain coesite or diamond and their respective peak metamorphic ages in Ma. Most of them are Phanerozoic in age and commonly related to major orogenetic cycles (i.e., Caledonian, Variscan, Alpine-Himalayan etc.). The youngest, at $4 \mathrm{Ma}$, is from Papua, New Guinea. The oldest are those related to the West Gondwana Orogen in Brazil and NW Africa, with ages greater than $600 \mathrm{Ma}$. The occurrence marked "Minas Gerais, $630 \mathrm{Ma}$ " is still under suspicion due to its uncertain location and lack of direct age dating of the sample. 
Himalayas. Such extreme metamorphism occurs along sutures due to very high temperatures and pressures and the internal rearrangement of material within subducted continental lithosphere, such as at depths $>100 \mathrm{~km}$, followed by rapid exhumation (Brown 2008).

The EAO, in turn, is a collage of continental cratonic nuclei, such as the Saharan, Congo, Kalahari, India, Madagascar, and Australia-Antarctica. Its northern part, the Arabian-Nubian Shield (ANS), represents an oceanic domain formed by island arc terranes with juvenile crust (Stern 1994). South of the ANS lies the Mozambique Belt, the main orogenic component of the EAO, with a complicated tectonic history involving continent-continent collisions among several cratonic masses with continental crust that are now located in Kenya, Tanzania, Madagascar, India, Sri Lanka, Zambia, Malawi, Mozambique, and Antarctica (Fritz et al.2013). Along the collisional sutures of the Southern part of the EAO, high mountains also resulted from crustal duplication produced by convergence and compressional orogenic deformation of continental crust.

Figure 3, adapted from Tsujimori et al. (2006), shows the location of UHP terrains, in which eclogites with coesite or diamond and their respective peak metamorphic ages have been identified. The oldest are those related to the WGO in Brazil and NW Africa with ages greater than $600 \mathrm{Ma}$. All others are Phanerozoic in age, some of them related to the Caledonian and Variscan belt in Greenland and Europe, and others related to the closure of the Paleo-Tethys and Neo-Tethys oceans to form Eurasia, when the East Gondwana sector of Pangea began to break up, disperse, and amalgamate. Particularly noteworthy are the Meso-Cenozoic UHP terrains linked to the Alpine-Himalayan collisional chain and the very recent age, $4 \mathrm{Ma}$, of the youngest known eclogites with coesite from Papua, New Guinea. Geothermal-barometric evidence indicates that coesite rocks can be exhumed from depths exceeding $100 \mathrm{~km}$, which means that crustal material produced by subduction of felsic continental crust less dense than the mantle may be subject to rapid isostatic rebound and exhumation to give rise to significant topographic relief, as in the Alps and Himalayas. Hence, these arguments indicate that the WGO registers the oldest known continent-continent collision, resulting in Himalayan-style mountain-building in Earth history. Similar to Ganade de Araujo et al. (2014b), the WGO mega-mountains were higher than any previous Neoproterozoic mountain belts and, therefore, a source of vast amounts of erosional sediments, part of which is preserved in the Ediacaran foreland basins and epicontinental seas of Gurma, Taoudeni, and Volta in Africa and Parecis, Paraguay, and Bambui in South America.

Furthermore, within the same Neoproterozoic time frame, at least three great Neoproterozoic glaciations took place, namely, the Sturtian (ca.720-660 Ma) and Marinoan (ca.650-636 Ma) glaciations, both considered as global in extent, or nearly so, and the more restricted Gaskiers glaciation ( $582 \mathrm{Ma}$ ) (Rooney et al. 2015, Spence et al. 2016). The Snowball Earth hypothesis (Kirschvink 1992, Hoffman et al. 1998) alleges that in each of these episodes the Earth was covered, or nearly so, by ice at least for a few million years. All continents contain evidence of this phase of Earth history, although the number of glaciations, their duration, and extent are still the subject of debate (see
Rooney et al. 2015). Similarly, the importance of these drastic climatic episodes upon microscopic life is unquestioned, although not much is known about just how they provoked or affected evolutionary changes.

Brasier and Lindsay (2001) suggested that the increased rate of sediment accumulation resulting from erosion of the high relief produced during the amalgamation of Gondwana could have influenced life radiation on Earth. This was supported by Squire et al. (2006) and Campbell and Squire (2010), who argued that massive sediment supply related to Gondwana assembly would have provided abundant nutrients (Meert and Lieberman 2008) for algae and cyanobacteria, and, consequently, a major stimulus for oxygen production by photosynthetic. The subsequent increase of $\mathrm{O}_{2}$ in the atmosphere and oceans would have been an important factor in the radiation of Late Neoproterozoic, and especially Ediacaran, life. In our view, the full implications of this innovation within the context of Rodinia breakup and Gondwana amalgamation have not still been unfathomed. However, the appearance of very high, open-air, ice-free mountains between about 620 and $570 \mathrm{Ma}$ in the aftermath of drastic Snowball Earth scenarios must have exerted a dramatic influence on climate, weathering, erosion, nutrient fluxes and carbon burial, with important consequences for the Earth system and especially as triggers for the evolution of Ediacaran life.

\section{PALEONTOLOGICAL EVIDENCE}

Uplift and denudation of Earth's first very high Himalayanstyle mountains along the TBK alignment began at about 615 to $610 \mathrm{Ma}$ and putatively continued for the following 40 to 50 million years during a very significant moment on Earth, and especially biosphere, history. Earlier to this event, life was preeminently microscopic, yet by the time it was over, macroscopic organisms, albeit many of them of enigmatic biological affinities, appeared and began to diversify in route to the crown group metazoans that we recognize today.

Let us examine briefly life during and after the so-called "boring billion" years of Earth history from about 1800 to $800 \mathrm{Ma}$. (Canfield 2005, Lyons et al. 2012, Knoll 2014, Planavsky et al. 2015). For this, we shall borrow upon the recent state-of-thescience overview of the Precambrian fossil record of Knoll and Nowak (2017). First, let us remember the extreme antiquity of life on Earth and the main biological innovations in the Precambrian (Knoll and Bambach 2000). Claims of the most ancient fossil evidence of life include carbon isotope signatures (Mojzsis et al. 1996, Bell et al. 2015), microbialites (Nutman et al. 2016), and microfossils (Dodd et al. 2017) with ages extending back to around $4 \mathrm{Ga}$, near the base of the known geological record. All, however, have been subject to considerable contention. Consequently, present consensus places the oldest reliable evidence of life on Earth from rocks about 3.45 Ga in age from the Warrawoona Group of Northwest Australia, in the form of putative stromatolites, microfossils and associated C and S isotope data (Schopf 2006, and references therein). This means that, independently of the biogenicity of older fossils, prokaryotic life proliferated and rose to dominance in benthic and planktic environments by mid-Archean and continued that 
dominance, certainly in benthic settings, even after the rise of unicellular eukaryotes (microalgae and other protists) in the later Paleoproterozoic (Knoll and Nowak 2017). In fact, it was these ancient prokaryotes, specifically the cyanobacteria, that furnished oxygen to the atmosphere via photosynthesis beginning no later than $2.7 \mathrm{Ga}$ and were responsible for the Great Oxygenation Event (GOE) in the early Paleoproterozoic around $2.4 \mathrm{Ga}$ (Holland 2006). A postulate of modern biology is that stable oxygen in the atmosphere provided an environmental stimulus that favored the appearance of unicellular eukaryotes, practically all of which are obligate aerobes that depend upon oxygen, later in the Paleoproterozoic, by at least 1.7-1.9 Ga.

Consensual geological evidence for the next great innovation in biological history, multicellular but still microscopic eukaryotes, dates from the mid-Mesoproterozoic, about 500 million years later. It consists of permineralized microscopic filamentous algae about $1200 \mathrm{Ma}$ old, which are very similar, in fact, to modern crown-group bangiophycean red algae (Butterfield 2000). One can only conclude that the origin of multicellularity certainly must have originated much earlier. Indeed, decimeter-scale organic compressions have been found in the Gaoyuzhuang Formation of North China just above putative evidence for a global oceanic oxygenation event. If their interpretation as macroalgae is correct, macroscopic multicellular eukaryotic algae may have originated a little after $1600 \mathrm{Ma}$ (Zhang et al. 2018). As such, this coincides with increased abundance and diversity of eukaryotic microalgae observed in other stratigraphic units in China, Siberia, and Australia (Knoll and Nowak 2017).
After the appearance of macroscopic algae, the dominance of marine prokaryotes, especially in benthic settings, began to falter, first, through competition for space and light and, nearly a billion years later, beginning about $600 \mathrm{Ma}$, as a consequence of the radiation of complex sessile and vagile macroscopic multicellular eukaryotes, including not only heterotrophic and autotrophic metazoans, but also other diverse organisms apparently unrelated to modern crown groups, known as vendobionts (Seilacher 1989, 1992, 2007). Moreover, phylogenomic analyses have demonstrated that by $730 \mathrm{Ma}$, in mid-Neoproterozoic time, just prior to the near-global Cryogenian "Snowball Earth" glaciations, many groups of amoeboid heterotrophic protists among unicellular eukaryotes had already attained crowngroup status (Lahr et al.2019). This is evidenced by late Tonian (800-720 Ma) vase-shaped microfossils (VSM), representative of at least two very separate groups of testate amoebae (Morais et al. 2019, and references therein; Lahr et al. 2019), as well as by other scale-bearing protists $(<811 \mathrm{Ma}$ ) (Cohen and Knoll 2012, Cohen et al. 2017). Younger agglutinated protists interpreted as foraminifera are reported from the mid-Cryogenian (Fritz et al. 2013), but evidence of metazoan body fossils older than $600 \mathrm{Ma}$ is limited to controversial tiny sponges and supposedly corroborative coeval or older sponge biomarkers (see discussion in Cunningham et al. 2017a, and references therein).

Surprisingly large vendobionts nearly 580 Ma old effectively mark the advent of continuous geological record of macroscopic metazoan and other animal-like body fossils (Narbonne and Gehling 2003), as seen in Figure 4. However, two exceptionally preserved fossil biotas (Konservat-Lagerstätten) in post-glacial

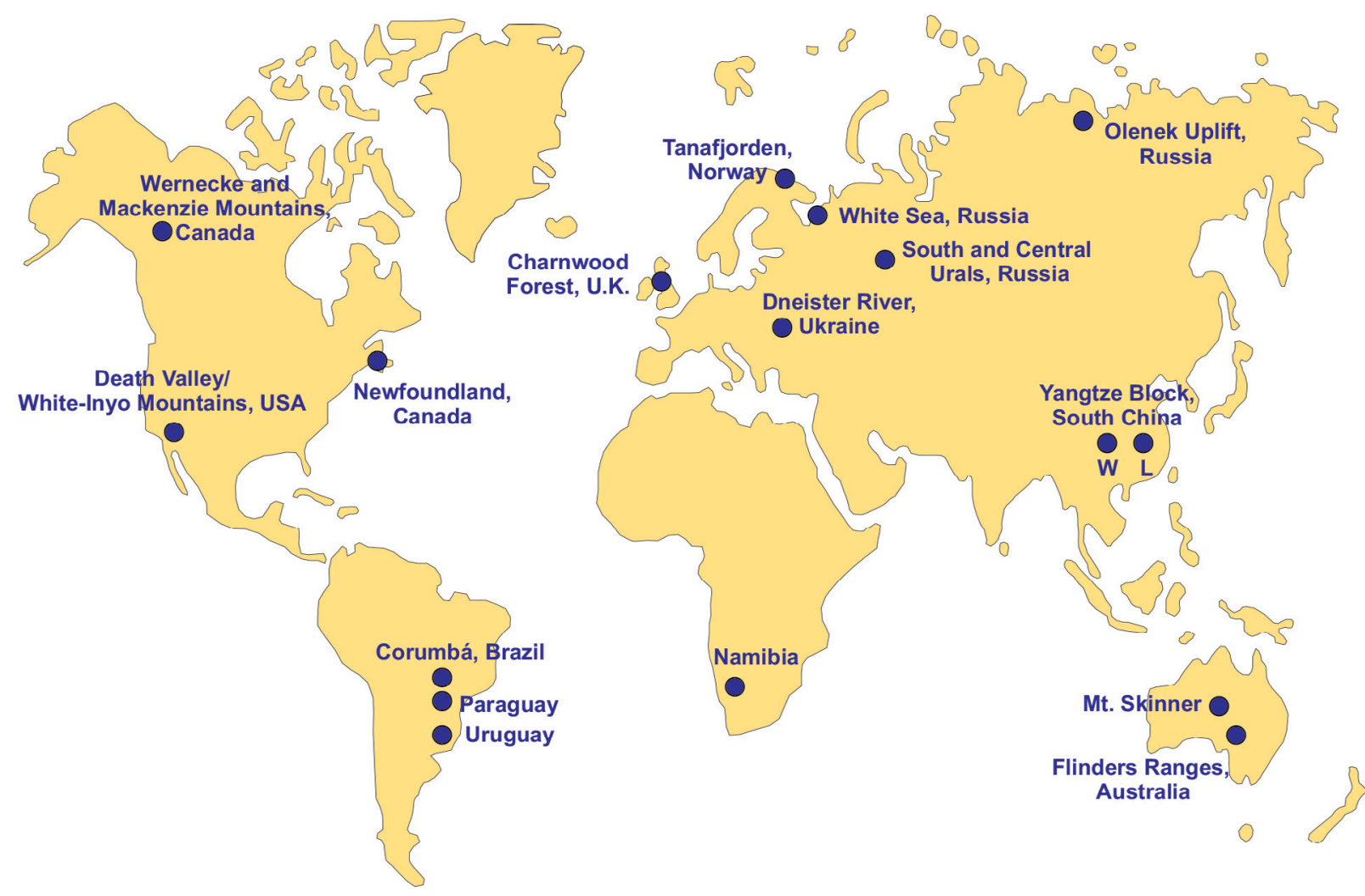

Figure 4. Main occurrences of macroscopic Ediacaran metazoans. The classic localities of the soft-bodied Avalon biota occur in Newfoundland and the UK. Those of the White Sea biota in NW Russia and Norway; and those of the Nama biota, in Namibia and Australia. The localities of the older Weng'an and Lantian biotas of South China are indicated by W and L, respectively. Locations after Laflamme et al. (2013). 
(= post-Marinoan) formations in China provide permissive evidence of a probably older Ediacaran record (Yuan et al. 2011, Xiao et al. 2014). The well-known Weng'an biota from phosphorites in the upper half of Doushantuo Formation (Xiao et al. 2014, and references therein; Cunningham et al. 2017a) could be as old as about $600 \mathrm{Ma}$, then the Lantian biota, from stratigraphically deeper pelites of the Lantian Formation, would have to be older than this (Yuan et al. 2011, Wan et al. 2016). Precise ages of these assemblages have yet to be established (Yuan et al. 2011, Xiao et al. 2014).

The Weng'an Biota (Figs. 5A-5F) consists of phosphatized and silicified microfossils (Liu et al. 2014, Xiao et al. 2014, Cunningham et al. $2017 \mathrm{~b}$ ) so well preserved three-dimensionally as to allow claims (not all without dispute) that they may represent animal embryos in various ontogenetic stages (Figs. 5A-5D), bilaterian animals, red and green algae (Fig. 5E), a sponge (Fig. 5F), acritarchs, and a ctenophore (Tang et al. 2008, Yin et al. 2015). In addition, two-dimensional carbonaceous compressions within the formation have been attributed to macroalgae (Xiao et al. 2002). A tuff bed overlying the fossil-bearing units dated at $609 \pm 5 \mathrm{Ma}(\mathrm{U}-\mathrm{Pb}$, Zhou et al. 2017) and acritarchs in the formation similar to immediately post-Marinoan (<635 Ma) formed elsewhere (Xiao et al.2014, Cunningham et al. 2017b) make the Weng'an assemblage a serious candidate for housing the oldest fossil evidence of embryonic, larval and adult eumetazoans, which are even older than the classical soft-bodied macroscopic Avalon, White Sea, and Nama Ediacaran biotas. Cunningham et al. (2017b, and references therein) reviewed the evidence and arguments regarding biological affinities of the Weng'an fossils and concluded that, although some might represent animals, none can yet be confidently identified as stem- or crown-group metazoans.

The Lantian biota (Figs. 5G-5I) consists of carbonaceous compression fossils preserved in place in carbonaceous pelites that were deposited below storm-wave base, yet still within the photic zone, judging from the alga-like morphologies of some of the fossils (Yuan et al. 2011). The biota represents about 15 morphospecies exhibiting complex morphological differentiation and reaching up to several centimeters in maximum dimension. The fossiliferous member of Lantian Formation may be correlated with strata in the Doushantuo Formation older than that containing the Weng'an biota, thus making the Lantian biota the earliest known well-preserved assemblage of varied macroscopic multicellular eukaryotes. Although many probably represent macroalgae (Fig. 5G), a few may arguably be cnidarians or worms (Figs. 5H and 5I) (Yuan et al. 2011, Wan et al. 2016); however, once again, this requires corroboration. The Lantian Formation is assuredly Ediacaran in age and possibly as old as $635 \mathrm{Ma}$; however, from a conservative point of view, all that can be said is that they are most likely older than $551 \mathrm{Ma}$ (Xiao et al. 2014).

The so-called vendobionts (Seilacher 1992, 2007), represented by dozens of taxa of fossilized soft-bodied, but firm macroscopic organisms, appear at about $580 \mathrm{Ma}$ and continue as the predominant elements of Ediacaran biotas worldwide till the end of the period at $541 \mathrm{Ma}$ (Figs. 4, 6A and 6B) (Wood et al. 2019). As summarized by Erwin et al. (2011), three distinct, bio-stratigraphically useful assemblages are recognized, each drawing its name from its most representative area of occurrence. The oldest, the Avalon assemblage (579 to $\sim 560 \mathrm{Ma}$ ) (Fig. 6A), known from Newfoundland and England, has been characterized by modular organisms built from repetitively branched ("fractal") units comprising the Rangeomorpha. Potential macroscopic sponges have also been recognized. The widespread White Sea assemblage $(\sim 560$ to $\sim 550 \mathrm{Ma})$ is more than three times more diverse in genera than the Avalon assemblage according to Erwin et al. (2011). It also includes diverse trace fossils, indicating increased eco-space occupation and behavioral complexity. The vagile mollusk-like soft-bodied Kimberella, that first appears in this assemblage is considered by Cunningham et al. (2017a) to be a total-group bilaterian, as is Dickinsonia (Fig. 6C) (Gold et al. 2015). The Nama assemblage is the youngest, $\sim 550$ to $541 \mathrm{Ma}$, and dominated by soft-bodied Erniettomorpha. However, it

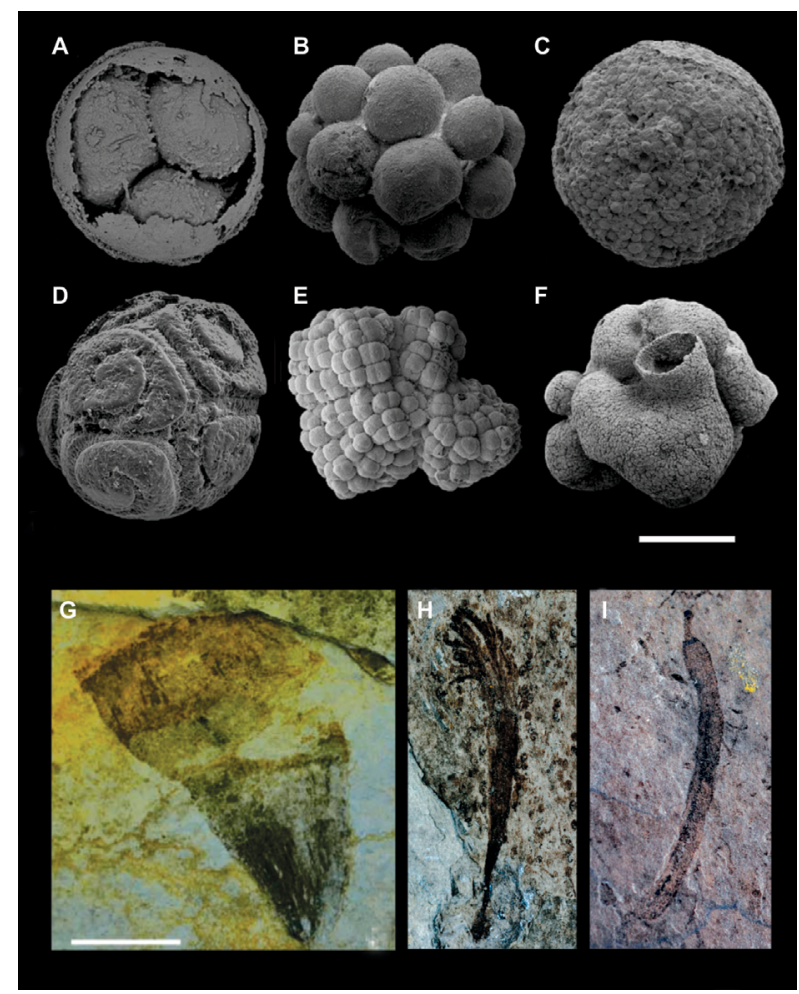

Figure 5. Representative fossils of the Weng'an biota (A-F) and Lantian biota (G-I) of South China. These biotas are older than the middle to late Ediacaran soft-bodied Avalon, White Sea and Nama macrobiotas (see Figs. 4 and 6). (A-F) Scanning electron microscope images of selected fossils of the Weng'an biota preserved in three dimensions. (A-C) Embryo-like fossil Tianzhushania exhibiting various stages of division, from a few cells (A) to many hundreds of cells (C). (D) Spiralicellula. (E) Archaeophycus, a putative red alga. (F) Eocyathispongia, suggested to be a sponge. (G-I) Representative fossils of the Lantian biota of South China preserved as compressions. (G) The macroalga Flabellophyton, with a fan-shaped or conical thallus. Scale $=5 \mathrm{~mm}$. (H) Lantianella, a putative scyphozoan cnidarian, approximately $36 \mathrm{~mm}$ long. (I) Xiuningella, a scalidophoran introvert(?), approximately $18 \mathrm{~mm}$ long. Scale bar in (F): (A) $265 \mu \mathrm{m}$, (B) $200 \mu \mathrm{m},(\mathrm{C}) 280 \mu \mathrm{m}$, (D) $380 \mu \mathrm{m}$, (E) $255 \mu \mathrm{m}$, (F) $415 \mu \mathrm{m}$. Image credits (A-F) from Cunningham et al. (2017b); (F) originally published by Tang et al. (2008); (E and F) originally published by Yin et al. (2015); (G) from Yuan et al. (2011); (H and I) from Cunningham et al. (2017a); images originally credited to $\mathrm{S}$. Xiao. 
also includes the oldest biomineralized macroscopic fossils (Xiao et al. 2014, Knoll and Nowak 2017) and fossils such as Corumbella (Fig. 6E) (Hahn et al. 1982, Pacheco et al. 2011, Warren et al. 2012) and Paraconularia (Van Iten et al. 2014, 2016), which Cunningham et al. (2017a) consider to be crowngroup metazoans (Scyphozoa). Holes in some biomineralized exoskeletons of the emblematic Nama fossil Cloudina have been interpreted as evidence of the predation (Bengtson and Yue 1992) that seems to have been fundamentally important in the subsequent radiation of biomineralizing metazoans marking the beginning of the Phanerozoic Eon and characterizing the Cambrian "explosion" of marine invertebrates (Erwin et al. 2011, Wood et al. 2019).

In light of the incompleteness regarding the early record of macroscopic fossils, evolutionary biologists have developed models - molecular clocks - that attempt to establish the divergence timing of evolutionary lineages in the Metazoa,

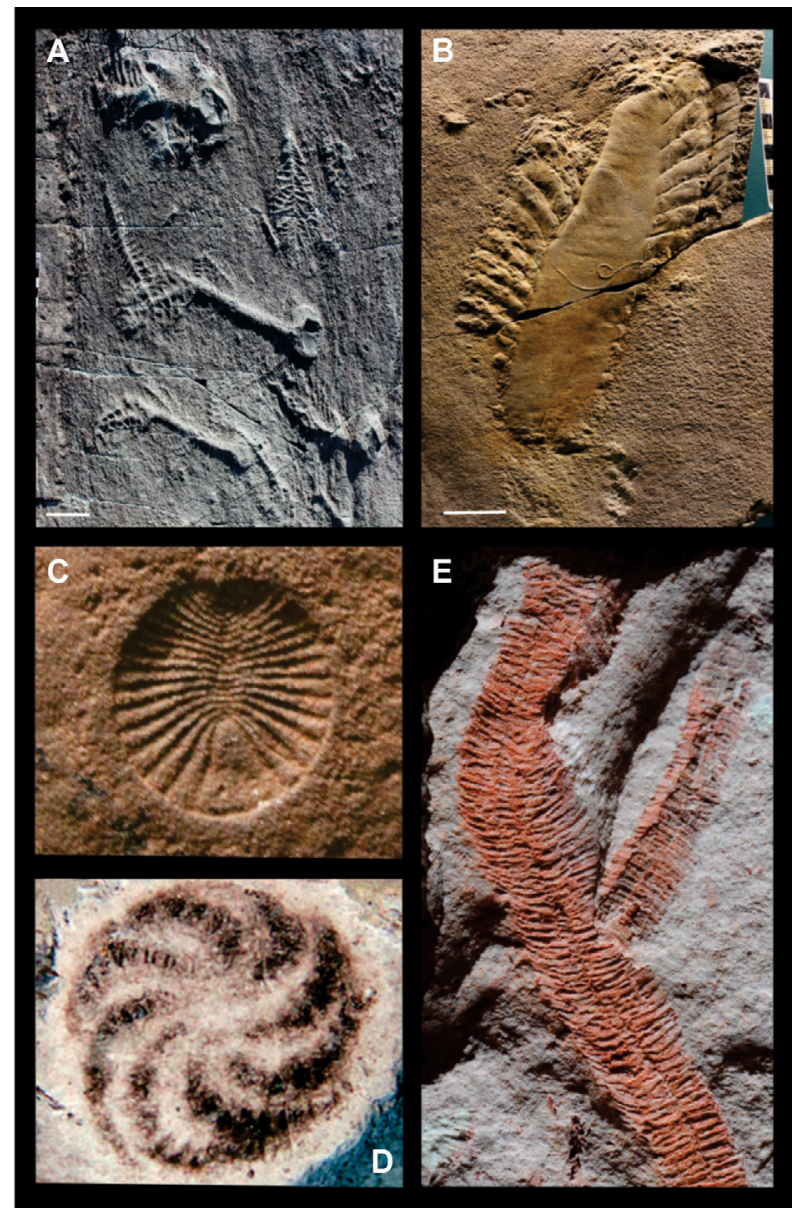

Figure 6. Representative taxa of middle to late Ediacaran macrobiotas. (A) Soft-bodied, frondose members of the Avalon macrobiota of Newfoundland, Canada, buried in place with holdfasts, stipes and fronds. Scale $=4 \mathrm{~cm}$. (B) Ediacaran Arborea with associated trace fossil; Flinders Ranges, South Australia. Smooth central part is $12.5 \mathrm{~cm}$ long. (C) Ediacaran crown-group metazoan (scyphozoan cnidarian) Corumbella, an organic-walled tubular fossil from Corumbá, Brazil (total length oflarger individual, $20 \mathrm{~mm}$ ). (D) Probable bilaterian eumetazoan Dickinsonia from the Flinders Range, Australia (length, $14 \mathrm{~mm}$ ). (E) Plausible stemgroup ctenophoran Eoandromeda from South China (diameter about $14 \mathrm{~mm}$ ). Image credits (A) and (B) from Wood et al. (2019). (C-E) from Cunningham et al. (2017a): original image credits: (C) L. Parry; (D) A. Liu; (E) Gehling and Rigby (1996). from stem groups to crown groups, based on the comparative analysis of amino acid sequences in proteins common to the biological groups under consideration. Molecular clocks depend upon estimates of molecular substitution rates, detection and correction of heterogeneities in these rates, choice of calibration points in the fossil record, choice of calibration strategy, and proper consideration of uncertainties in these parameters (Peterson et al. 2004, Cunningham et al. 2017a). They date from the 1980s (Runnegar 1982, 1986) and figure importantly in the current understanding of early metazoan evolution in the Neoproterozoic, as shown in Figure 7 (based on Dos Reis et al.2015). The crucial point in the configuration by Dos Reis et al. (2015) is their choice of calibration points from the geological record of body fossils, trace fossils, and biomarkers (geologically stable organic compounds diagenetically derived solely from known biological precursors) for the nodes that mark major phylogenomic divergences, such as the appearance of the Eumetazoa, Bilateria, Deuterostomia/ Protostomia, and so on.

Dos Reis et al. (2015) admit that: "Much of the molecular genetic toolkit required for animal development originated deeply in eukaryote evolutionary history". Hence, the appearance of complex multicellular animals in the geologic record may have been limited or triggered by such factors as biosphere oxygenation, scarcity of trace metal micronutrients, pulse of continental weathering in nutrient flows to the oceans, and environmental restrictions imposed by extreme Cryogenian and Ediacaran icehouse scenarios, among others (Dos Reis et al. 2015, and references therein). They further argue that uncertainties regarding the nature of ancient fossils together with violations of the molecular clock models are such that it is not possible to accurately pinpoint early divergence events in metazoan evolution from the available fossil data and molecular clock models.

To Cunningham et al. (2017a), however, critical reexamination of the fossil evidence reveals a much less bleak picture for the early metazoan evolution. The most widely cited evidence for metazoans in rocks predating accepted Ediacaran body fossils are the biomarker 24-isopropylcholesterol attributed to demosponges (Love et al.2009) in rocks about $635 \mathrm{Ma}$-old from Oman and Cryogenian sponge bioclasts in the Trezona Formation of Australia (Maloof et al.2010), yet they, too, are subject to debate, as summarized by Cunningham et al. (2017a). Nevertheless, these and other key findings provide a pattern of fossil evidence that is consistent with the molecular clock model (Fig. 7) of dos Reis et al. (2015). Together, they suggest that the Metazoa originated no later than $635 \mathrm{Ma}$; and the divergence and initial diversification of bilaterians likely occurred prior to about $560 \mathrm{Ma}$. A closer fit between the fossil record and molecular clocks is hampered by problems of preservation and identification of biological affinities of these and older possible animal fossils, given that they must include stem-group organisms with unfamiliar and commonly poorly preserved character sets. All would agree, however, that the major diversification of the Metazoa that sets the stage for Phanerozoic animal evolution was indeed an Ediacaran phenomenon. 


\section{DISCUSSION AND CONCLUSIONS}

At the end of the "boring billion" years in the history of life (Canfield 2005, Lyons et al. 2012, Knoll 2014, Planavsky et al. 2015), a succession of Earth-changing events involving crustal, atmospheric and hydrosphere dynamics and chemistry impinged itself upon life systems. This new complex and dynamic environment effectively transformed the long-reigning microbe-dominated ecosystems into a rapidly evolving macroscopic biosphere capable of ever more complex interactions and presenting greater physical presence within the Earth system (Knoll and Bambach 2000).

Primary among the events affecting the biosphere was the oxygen increase in the atmosphere and oceans beginning in mid-Neoproterozoic and perhaps reaching $40 \%$ of the present atmospheric level (PAL) by $550 \mathrm{Ma}$ (Sperling et al. 2015). It is now a consensus that physical and chemical processes of carbon recycling, acting during the latter half of the Neoproterozoic, beginning about $800 \mathrm{Ma}$, were largely responsible for elevating the oxygen level in the atmosphere and oceans to evolutionarily significant thresholds over the remainder of the terminal Neoproterozoic. Whether this phenomenon, dubbed the Neoproterozoic Oxygenation Event (NOE) (Och and Shields-Zhou 2012, also see Planavsky et al. 2015, Spence et al. 2016), was episodic or continuous is still under debate, but most researchers accept it as a fundamental factor in the expansion of multicellular eukaryotes. Indeed, by the very early Paleozoic, increased oxygen availability allowed the introduction of complex, active and multicellular macroscopic eukaryotes into the biosphere. This is a level of complexity that it sustains to the present day (Sperling et al. 2013).

Of the various reasoning lines offered as evidence for this event, the most important in the present context are those that demonstrate a continuous increase in ${ }^{87} \mathrm{Sr} /{ }^{86} \mathrm{Sr}$ values in seawater and generally high $\delta^{13} \mathrm{C}$ values in carbonates in the Neoproterozoic after about $800 \mathrm{Ma}$ (Veizer 1989, Halverson et al. 2007, Halverson et al. 2010). These tendencies may be explained, respectively, by the increasing rates of continental weathering as responsible for radiogenic strontium input into

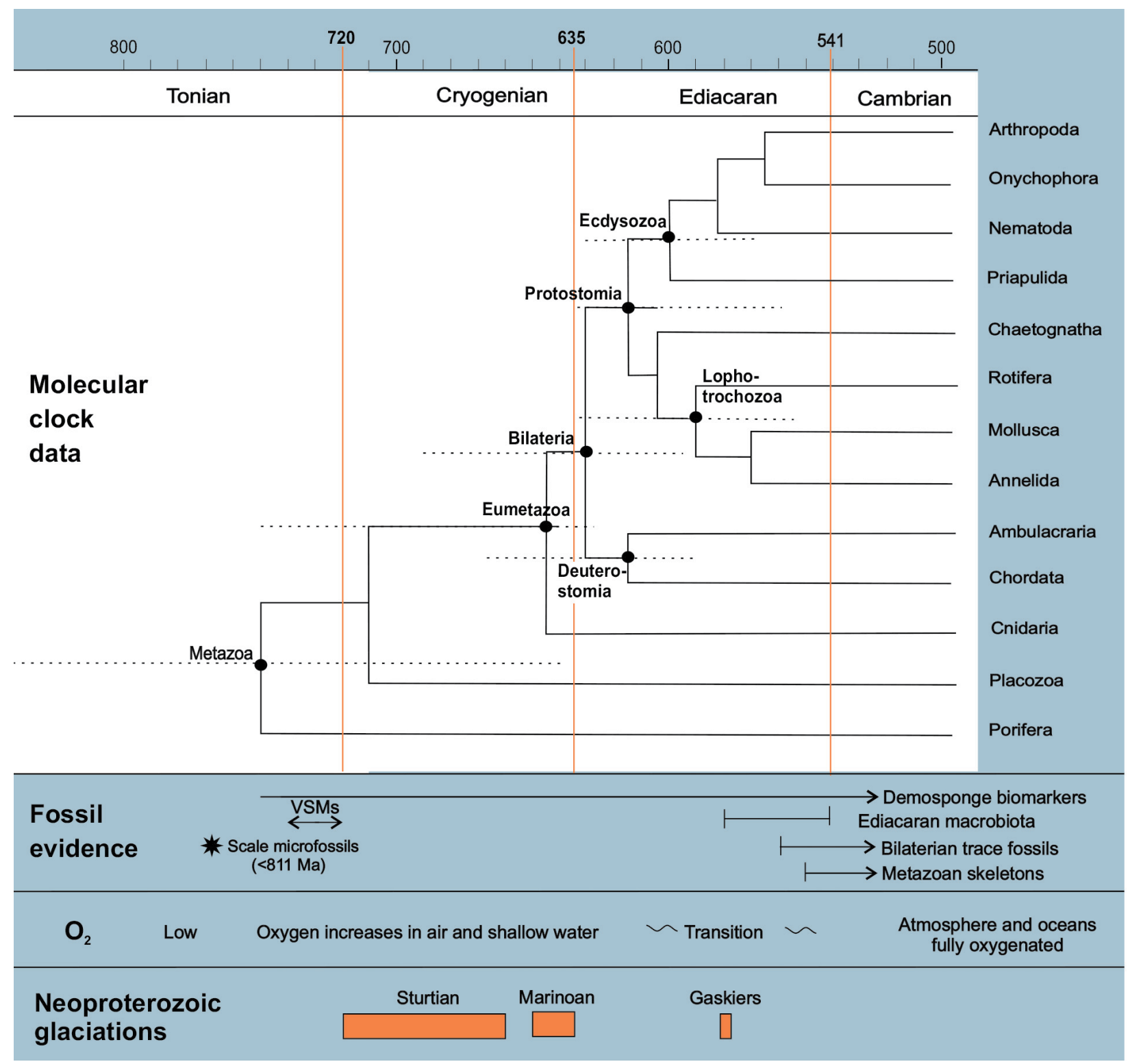

Figure 7. Molecular clock data for main events in the early animal evolution (adapted from Cunningham et al. 2017a) together with relevant fossil evidence, Neoproterozoic oxygenation history, and record of Neoproterozoic glaciations (see text for explanations). Phylogeny, position of nodes (large dots), and thin dotted node bars (encompassing uncertainty in estimating node position in time) are those of Dos Reis et al. (2015). 
the oceans and by relatively high sustained rates of organic matter burial (derived from mostly unicellular prokaryotic and eukaryotic micro-phytoplankton) (Meert and Lieberman 2008, Och and Shields-Zhou 2012). The sequestration of organic carbon by burial, together with the withdrawal of atmospheric $\mathrm{CO}_{2}$ by continental weathering, would have: liberated $\mathrm{O}_{2}$ that otherwise would have been consumed in the oxidation of the sequestered organic matter; increased the flow of nutrients to photoautrophs in the oceans (favoring high levels of primary production); and reduced the participation of $\mathrm{CO}_{2}$ in the greenhouse effect, leading to a cooler atmosphere.

Just as earlier Paleoproterozoic GOE between 2.4 and 2.0 Ga (Holland 2006) favored the emergence and radiation of the unicellular eukaryotes, not only capable of $\mathrm{O}_{2}$-powered metabolism but, in fact, also dependent upon oxygen, the NOE, more than a billion years later, elevated oxygen levels in the atmosphere and oceans sufficiently to allow heterotrophic eukaryotes to exploit pluricellular body plans on a macroscopic scale. This was something that putative decimetric eukaryotic photoautotrophs (macroalgae) from China (Zhang et al.2018) had apparently achieved, under less oxygenic conditions, by about $1500 \mathrm{Ma}$. They, however, could produce oxygen to their own system through photosynthesis; and their increased size was likely advantageous in terms of photosynthetic area and competition for space on the sea floor. The soft-bodied macroscopic forms that appeared in the Ediacaran much later are interpreted as heterotrophic pluricellular organisms, dependent upon higher levels of ambient oxygen. Initially, these included the enigmatic vendobionts as well as difficult-to-classify stemgroup metazoans, but by $560 \mathrm{Ma}$ eumetazoans were also included (Fig. 7). How these animals lived has not been always clear, and some may even have been sessile osmotrophs, but several bilaterians are now recognized, such as Kimberella and Dickinsonia (Cunningham et al. 2017a and references therein). Clearly, from what we know of how eukaryotes function and reproduce, the NOE afforded unprecedented opportunities for eukaryote evolution at macroscopic pluricellular levels and a new level of ecospace opportunities to exploit novel body plans, physiologies, and growth and feeding strategies (Knoll and Bambach 2000).

The appearance of multicellular eukaryotes, even prior to attaining macroscopic size, could have also influenced the atmosphere oxygenation and ventilation of the oceans. For example, the advent of fecal pellets and greater body size in eukaryotic organisms would have increased sinking rates of organic carbon, thus shortening both residence time in the water column and exposure to microbial decomposers. This would have facilitated carbon incorporation (sequestration) within sediments, thereby favoring oxygen accumulation (Lenton et al.2014, and references therein). By the same token, Neoproterozoic colonization of the surface of the continents by microorganisms (Horodyski and Knauth 1994) could have promoted $\mathrm{CO}_{2}$ drawdown from the atmosphere and more efficient weathering of silicates and micronutrient delivery to the oceans. Finally, in the latter half of the Ediacaran, the appearance of infaunal organisms capable of intensely utilizing the substrate prompted nothing less than a "revolution" in redox conditions in near-surface sediments and ecospace exploitation (Seilacher 1999, Bottjer et al. 2000).

Three extreme paleoclimatic changes, the Sturtian, Marinoan and Gaskiers glacial events, the severest ever registered in the geologic record, also occurred concomitantly with the breakup of Rodinia, Gondwana amalgamation, and early metazoan evolution. The Snowball Earth hypothesis put forward to explain these events (Kirschvink 1992, Hoffman et al. 1998, Spence et al.2016) asserts that the Earth was totally covered, or nearly so, by ice, several times between 720 and 580 Ma. Rocks on all continents record one or more of these glaciations, yet the precise age and temporal equivalence of glacial events have been difficult to be established because their most emblematic sedimentary signature, diamictites, cannot be directly dated, unless intercalated by contemporaneous beds of volcanic materials, which is rare. Much more commonly, maximum depositional ages have been deduced from $\mathrm{U}-\mathrm{Pb}$ ages of the youngest detrital zircons within the diamictites, whereas minimum ages have been furnished by $\mathrm{Pb}-\mathrm{Pb}$ age-determinations for immediately post-glacial cap carbonates, when present.

Current evidence indicates that the Sturtian event started at about $717 \mathrm{Ma}$ (Rooney et al. 2015, and references therein). The best available ages for Sturtian rocks have been obtained in ash beds intercalated within diamictites from Oman, which yielded U-Pb zircon ages of $723 \pm 16 \mathrm{Ma}$ and $711.5 \pm 0.3 \mathrm{Ma}$ (Brasier et al. 2000, Bowring et al. 2007). Ash beds of the Mount Harper Group from Canada (Macdonald et al. 2010), dated by the chemical abrasion - isotope dilution - thermal ionization mass spectrometer (CA-ID-TIMS U-Pb) method, yielded a precise age of $716.33 \pm 0.54 \mathrm{Ma}$. Re-Os ages of about $659 \mathrm{Ma}$ (Kendall et al. 2006, Rooney et al. 2014, 2015) of the youngest cap carbonates associated with this glaciation suggest that Sturtian glacial events took place over nearly $60 \mathrm{Ma}$, from about 717 to $660 \mathrm{Ma}$ (Rooney et al.2015, Hoffman et al.2017). Some authors argue that Sturtian glaciation encompasses several shorter glacial episodes (Le Heron et al. 2013). In Brazil, a $\mathrm{Pb}$-Pb isochron age of $740 \pm 22 \mathrm{Ma}$, obtained on cap carbonates from Sete Lagoas Formation (Babinski et al. 2007), is consistent with their correlation with the Sturtian event.

The best age for the Marinoan glacial event is $636 \mathrm{Ma}$, as indicated by the U-Pb age of $635.5 \pm 1.2 \mathrm{Ma}$ on zircon from ash beds interlayered in diamictites of the Ghaub Formation, Namibia (Hoffmann et al.2004). A nearly identical age of 636.3 $\pm 4.9 \mathrm{Ma}$ was obtained on zircon grains from an ash bed in Nantuo Formation, China (Zhang et al. 2008). Post-Marinoan cap carbonates have yielded very similar ages. Condon et al. (2005), for example, obtained an ID-TIMS U-Pb age of 635.2 $\pm 0.6 \mathrm{Ma}$ for zircons from an ash bed intercalated within cap carbonates overlying the Nantuo tillite on Yangtze Platform, China. $\mathrm{Pb}-\mathrm{Pb}$ isochrons on post-Marinoan cap carbonates at the base of the Araras Group in Brazil yielded ages of $633 \pm$ $25 \mathrm{Ma}$ (Babinski 2011) and 622 $233 \mathrm{Ma}$ (Romero et al. 2013).

Finally, diamictites representing the much more restricted mid-Ediacaran Gaskiers Glaciation in Eastern Canada contain many ash beds in the type section that have been precisely dated within the interval from 581 to $579 \mathrm{Ma}$ by Bowring et al. (2003) and Pu et al. (2016). It is noteworthy that the same 
region is the site of the classical localities of the soft-bodied Avalon fossil macrobiota (Hofmann et al. 2008, Shen et al. 2008, Knoll 2014).

The extreme climates associated with the initiation, maintenance, and termination of these worldwide glacial events must have had a significant effect on the biosphere, but not much is known about how they provoked or affected subsequent evolutionary changes, either as a bottleneck and/or as a trigger for adaptive innovations. As evident from the fossil record and described earlier, microscopic prokaryotic and eukaryotic lineages, as well as putative macroscopic algae and possibly sponges, obviously survived the snowball scenarios of the Cryogenian (720 to $635 \mathrm{Ma}$ ). A pronounced spike in marine phosphorous, an essential nutrient, during this period (Planavsky et al. 2010) suggests that massive amounts of nutrients (including phosphorus) may have been delivered to the seas as a product of glacial erosion during deglaciation following individual glacial episodes at this time. Together with concomitant eustatic sea level rise, this certainly must have favored colonization of benthic and planktonic habitats in the vast shallow seas that spread over low-lying, glacially planed continental margins. Their resultant increase in primary production, oxygenation, and habitat diversification undoubtedly transformed the biosphere and presented new evolutionary options. As a possible example of this, we see relatively complex and diverse eukaryotic biotas for the first time at Lantian and Weng'an (Yuan et al.2011, Xiao et al.2014, Cunningham et al. 2017a, 2017b) in the interval between the Marinoan and Gaskiers glaciations (635 to $580 \mathrm{Ma}$ ). Moreover, typical, large soft-bodied elements of the Ediacaran macrobiota, the oldest known vendobionts, date from just after the Gaskiers event at $579 \mathrm{Ma}$ in rocks from the classical region for that event (Knoll 2014, Knoll and Nowak 2017) (Fig. 7). Shortly thereafter, bilaterians, as inferred from trace fossils, appeared between 570 and $566 \mathrm{Ma}$ and bona fide bilaterian metazoan fossils showed up at $558 \mathrm{Ma}$.

As stated by Planavsky et al. (2015, p. 27): "How and when the Earth moved beyond the 'boring billion', in phase with extreme glaciations, increased oxygenation, and ultimately the emergence of animals, remain among the crucial questions in the history of Earth-life co-evolution". In our view, "How" remains an open question currently within the domains of molecular and developmental biology, organic chemistry, and geochemistry, but "When", on the other hand, is an issue that we address in this paper using biological, climatic, and tectonic lines of evidence. Although recognizing the relevance of the oxygen rise in the oceans and climatic extremes in this discussion, we argue specifically that the main trigger for the emergence (and maintenance) of modern ecosystems dominated by macroscopic organisms was tectonic, related to the first appearance of high surface relief involving Himalayantype mega-mountains within the WGO.

As explained above, the Transbrasiliano-Kandi lineament, stretching 5,000 km from Brazil to Africa and marking the site of the WGO, records the oldest evidence of a continent-continent collision capable of producing very high mountain chains (Ganade de Araujo et al. 2014b). Such mountains were probably comparable to the present Himalayas and may have been at least as long-lived. The central Tibetan plateau, for example, has maintained elevations greater than 5,000 m, with many peaks surpassing 8,000 m, since the Eocene (REF). By analogy, then, mega-mountains in Gondwana may also have sustained similar high relief for at least $40 \mathrm{Ma}$ after the original collision responsible for their formation.

Therefore, if the WGO originated near $610 \mathrm{Ma}$ (Ganade de Araujo et al. 2014b) in association with high Himalayanlike mountains, it could have persisted at least until $580 \mathrm{Ma}$. During this time and through the period of erosion until $540 \mathrm{Ma}$, as estimated from the age of several post-collisional granitoids (Ganade de Araujo et al. 2014a), they have most certainly served as a major source of sediments and nutrients for contemporaneous seas. Just as the Tibetan plateau exerts a profound influence on modern climate, sedimentation, tectonics and biology, the same was probably true for the WGO during the Ediacaran as well. Note that the chronology of these events in Figure 2 corresponds closely with important events in the evolution of macroscopic eukaryotes shown in Figure 7.

As indicated, several places in the WGO expose low or UHP metamorphic rocks typical of the diagnostic prototypes that characterize deep continental subduction, such as observed in modern plate tectonics (Ganade de Araujo et al. 2014a). UHP rocks in Mali dated at about $620 \mathrm{Ma}$ (Jahn et al. 2001, Ganade de Araujo et al. 2014a) thus comprise the earliest evidence not only of large-scale deep-continental subduction, but consequently also of Himalayan-type mountains. Hence, the uplift and subsequent erosion of these mountains in the Late Ediacaran (Fig. 2) provided massive amounts of sediments and nutrients throughout the most important phase in the emergence and early diversification of megascopic metazoans on Earth.

Thus, we consider that the WGO, harboring as it does the oldest evidence of Himalayan-style relief resulting from continent-continent collisions, is one of the features that changed the way evolution proceeded on Earth in the Ediacaran. Figure 3 illustrating the distribution and ages of all known localities of UHP metamorphic rocks shows that none of them is older than those of the WGO. Moving forward in time, note that UHP metamorphic rocks indicating deep subduction occur within collisional belts associated with globally important tectonic cycles throughout the Phanerozoic, as in the Caledonian, Hercynian, and Alpine cycles. The high mountain ranges they represent are, in fact, a characteristic of Phanerozoic times. The implication is that they have furnished nutrients to the seas through weathering and erosion sufficient enough to sustain intense eukaryotic evolution and permit an increasingly complex exploitation of ecospace within the biosphere throughout the Phanerozoic (Knoll and Bambach 2000).

Hence, what might we expect from future research suggested by this hypothesis? First, we expect that similar work on the EAO will add further support for the relevance of Gondwana amalgamation as an important influence upon the acceleration of biological evolution at the Neoproterozoic end. For instance, we expect that investigation of high-pressure metamorphic rocks already known in Tanzania and 
Mozambique and related to the collisions of India, Madagascar and Australia-Antarctica with the Central African Block, may well confirm the suspicion that mega-mountains were likewise formed in the Southern part of the EAO. Second, it will also be important to test the hypothesis presented here by means of source-to-sink investigations of delivery rates of nutrients and their bioavailability in basins fed by the erosion of mega-mountains. Regarding the WGO, answers to these questions may be found in basins related to the dissection of high mountains associated, for example, with the Voltaian basin in Ghana or the Parecis basin in Brazil. As in all of Geology, time will tell.

\section{ACKNOWLEDGEMENTS}

The authors acknowledge the invitation received from Prof. Alcides Sial, Guest Editor of the BJG, to make this special contribution to a volume in honor of Edilton José Santos. Edilton, who left us so prematurely, dedicated his academic life to the geology of Northeast Brazil and produced significant academic and technical studies on the Borborema tectonic province. We thank the following personnel of Instituto de Geociências, Universidade de São Paulo: Thelma Collaço Samara for drafting and mounting the figures; Célia Regina de Oliveira Rosa and Anderson de Santana for organizing and correcting references.

\section{ARTICLE INFORMATION}

Manuscript ID: 20190095. Received on: 09/18/2019. Approved on: 02/28/2020.

U.C. proposed the idea and structure of the paper and prepared the first draft of the manuscript; T.F. contributed in the paleontological section with some of the figures and wrote the final version of the manuscript; C.G. improved the manuscript through suggestions for the section on "Modern-type" tectonics; M.B. improved the manuscript through suggestions for the section on the Ediacaran glaciations; J.L. contributed in the paleontological section and prepared some of the figures.

Competing interests: The authors declare no competing interests.

\section{REFERENCES}

Babinski M. 2011. Geocronologia das glaciações criogenianas do Brasil Central. Thesis, Instituto de Geociências, Universidade de São Paulo, São Paulo. https://doi.org/10.11606/T.44.2013.tde-26072013-151419

Babinski M., Vieira L.C., Trindade R.I.F. da. 2007. Direct dating of the Sete Lagoas cap carbonate (Bambuí Group, Brazil) and implications for the Neoproterozoic glacial events. Terra Nova, 19(6), 401-406. https://doi. org/10.1111/j.1365-3121.2007.00764.x

Bell E.A., Boehnke P., Harrison T.M., Mao W.L. 2015. Potentially biogenic carbon preserved in a 4.1 billion-year-old zircon. Proceedings of the National Academy of Sciences, 112(47), 14518-14521. https://doi.org/10.1073/ pnas. 1517557112

Bengtson, S., Yue, Z. 1992. Predatorial borings in late Precambrian mineralized exoskeletons. Science, 257, 367-369.

Bottjer D.J., Hagadorn J.W., Dornbos S.Q. 2000. The Cambrian substrate revolution. GSA Today, 10(9), 1-7.

Bowring S.A., Grotzinger J.P., Condon D.J., Ramezani J., Newall M.J., Allen P.A. 2007. Geochronologic constraints on the chronostratigraphic framework of the Neoproterozoic Huqf Supergroup, Sultanate of Oman. American Journal of Science, 307(10), 1097-1145. https://doi. org/10.2475/10.2007.01

Bowring, S.A., Myrow, P.M., Landing, E., Ramezani, J. 2003. Geochronological constraints on terminal Neoproterozoic events and the rise of metazoans. Geophysical Research Abstracts, 5, 219

Brasier M., McCarron G., Tucker R., Leather J., Allen P., Shields G. 2000. New U-Pb zircon dates for the Neoproterozoic Ghubrah glaciation and for the top of the Huqf Supergroup, Oman. Geology, 28(2), 175-178.

Brasier M.D., Lindsay J.F. 2001. Did supercontinental amalgamation trigger the "Cambrian Explosion"? In: Zhuralev A.Y., Riding R. (Eds.). The Ecology of the Cambrian Radiation. Columbia: Columbia University Press, p. 69-89.

Brown M. 2008. Characteristic thermal regimes of plate tectonics and their metamorphic imprint throughout Earth history: When did Earth first adopt a plate tectonics mode of behavior? In: Condie K.C. and Pease V. (eds.). When Did Plate Tectonics Begin on Planet Earth? America: Geological Society of America Special Paper, v. 440, p. 97-128. https://doi. org/10.1130/2008.2440(05)
Butterfield N.J. 2000. Bangiomorpha pubescens n. gen., n. sp.: implications for the evolution of sex, multicellularity, and the Mesoproterozoic/ Neoproterozoic radiation of eukaryotes. Paleobiology, 26(3), 386-404. https://doi.org/10.1666/0094-8373(2000)026<0386:BPNGNS>2.0.CO;2

Caby R. 1994. Precambrian coesite from northern Mali: first record and implications for plate tectonics in the trans-Saharan segment of the PanAfrican belt. European Journal of Mineralogy, 6(2), 235-244. https://doi. org/10.1127/ejm/6/2/0235

Campbell I.H., Squire R.J. 2010. The mountains that triggered the Late Neoproterozoic increase in oxygen: The Second Great Oxidation Event. Geochimica et Cosmochimica Acta, 74(15), 4187-4206. https://doi. org/10.1016/j.gca.2010.04.064

Canfield D.E. 2005. The early history of atmospheric oxygen: Homage to Robert M. Garrels. Annual Review of Earth and Planetary Sciences, 33, 1-36. https://doi.org/10.1146/annurev.earth.33.092203.122711

Cawood P.A., Hawkesworth C.J., Pisarevsky S.A., Dhuime B., Capitanio F.A., Nebel O. 2018. Geological archive of the onset of plate tectonics. Philosophical Transactions of the Royal Society A, 376, 20170405. http:// dx.doi.org/10.1098/rsta.2017.0405

Cohen P.A., Knoll A.H. 2012. Scale microfossils from the midNeoproterozoic Fifteenmile Group, Yukon Territory. Journal of Paleontology, 86(5), 775-800. https://doi.org/10.1666/11-138.1

Cohen P.A., Strauss J.V., Rooney A.D., Sharma M., Tosca N. 2017. Controlled hydroxyapatite biomineralization in an $\sim 810$ million-yearold unicellular eukaryote. Science Advances, 3(6), e1700095. https://doi. org/10.1126/sciadv. 1700095

Condon D., Zhu M., Bowring S., Wang W., Yang A., Jin Y. 2005. U-Pb ages from the Neoproterozoic Doushantuo Formation, China. Science, 308(5718), 95-98. https://doi.org/10.1126/science.1107765

Cordani U.G., Pimentel M.M., Araújo C.E.G. de, Fuck R.A. 2013. The significance of the -Transbrasiliano-Kandi tectonic corridor for the amalgamation of West Gondwana. Brazilian Journal of Geology, 43(3), 583597. https://doi.org/10.5327/Z2317-48892013000300012

Cunningham J.A., Liu A.G., Bengtson S., Donoghue P.C.J. (2017a). The origin of animals: Can molecular clocks and the fossil record be reconciled? BioEssays, 39(1), 1-12. https://doi.org/10.1002/bies.201600120 
Cunningham J.A., Vargas K., Yin Z., Bengtson S., Donoghue P.C.J. (2017b). The Weng'an Biota (Doushantuo Formation): an Ediacaran window on softbodied and multicellular microorganisms. Journal of the Geological Society, 174(5), 793-802. https://doi.org/10.1144/jgs2016-142

Dodd M.S., Papineau D., Grenne T., Slack J.F., Rittner M., Pirajno F., O’Neil J., Little C.T.S. 2017. Evidence for early life in Earth's oldest hydrothermal vent precipitates. Nature, 543, 60-64. https://doi.org/10.1038/ nature 21377

Dos Reis M., Thawornwattana Y., Angelis K., Telford M.J., Donoghue P.C.J., Yang Z. 2015. Uncertainty in the timing of origin of animals and the limits of precision in molecular timescales. Current Biology, 25(22), 2939-2950. https://doi.org/10.1016/j.cub.2015.09.066

Erwin D.H., Laflamme M., Tweedt S.M., Sperling E.A., Pisani D., Peterson K.J. 2011. The Cambrian conundrum: early divergence and later ecological success in the early history of animals. Science, 334(6059), 1091-1097. https://doi.org/10.1126/science.1206375

Fritz H., Abdelsalam M., Ali K.A., Bingen B., Collins A.S., Fowler A.R., Ghebreab W., Hauzenberger C.A., Johnson P.R., Kusky T.M., Macey P., Muhongo S., Stern R.J., Viola G. 2013. Orogen styles in the East African Orogen: A review of the Neoproterozoic to Cambrian tectonic evolution. Journal of African Earth Sciences, 86, 65-106. https://doi.org/10.1016/j. jafrearsci.2013.06.004

Ganade de Araujo C.E., Cordani U.G., Weinberg R., Basei M.A.S., Armstrong R., Sato K. (2014a). Tracing Neoproterozoic subduction in the Borborema Province (NE-Brazil): clues from U-Pb geochronology and $\mathrm{Sr}$ $\mathrm{Nd}-\mathrm{Hf}-\mathrm{O}$ isotopes on granitoids and migmatites. Lithos, 202-203, 167-189. https://doi.org/10.1016/j.lithos.2014.05.015

Ganade de Araujo C.E., Rubatto D., Hermann J., Cordani U.G., Caby R., Basei M.A.S. 2014b. Ediacaran 2,500-km-long synchronous deep continental subduction in the West Gondwana Orogen. Nature Communications, 5 5198. https://doi.org/10.1038/ncomms6198

Gehling J.G., Rigby J.K. 1996. Long expected sponges from the Neoproterozoic Ediacara fauna of South Australia. Journal of Paleontology, 70(2), 185-195. https://doi.org/10.1017/S0022336000023283

Gold D.A., Runnegar B., Gehling J.G., Jacobs D.K. 2015. Ancestral state reconstruction of ontogeny supports a bilaterian affinity for Dickinsonia. Evolution \& Development, 17(6), 315-324. https://doi.org/10.1111/ ede. 12168

Hahn, G., Hahn, R., Leonardos, O.H., Pflug, H.D., Walde, D.H.G. 1982. Kfrperlich erhaltene Scyphozoen-Reste aus dem Jungprekambrium Brasiliens. Geologica et Paleontologica, 16, 1-18.

Halverson G.P., Dudás F.Ö., Maloof A.C., Bowing S.A. 2007. Evolution of the ${ }^{87} \mathrm{Sr} /{ }^{86} \mathrm{Sr}$ composition of Neoproterozoic seawater. Palaeogeography, Palaeoclimatology, Palaeoecology, 256(3-4), 103-129. https://doi. org/10.1016/j.palaeo.2007.02.028

Halverson G.P., Wade B.P., Hurtgen M.T., Barovich K.M. 2010. Neoproterozoic chemostratigraphy. Precambrian Research, 182(4), 337 350. https://doi.org/10.1016/j.precamres.2010.04.007

Hoffman P.F., Abbot D.S., Ashkenazy Y., Benn D.I., Brocks J.J., Cohen P.A., Cox G.M., Creveling J.R., Donnadieu Y., Erwin D.H., Fairchild I.J., Ferreira D., Goodman J.C., Halverson G.P., Jansen M.F., Le Hir G., Love G.D., Macdonald F.A., Maloof A.C., Partin C.A., Ramstein G., Rose B.E.J., Rose C.V., Sadler P.M., Tziperman E., Voigt A., Warren S.G. 2017. Snowball Earth climate dynamics and Cryogenian geology-geobiology. Science Advances, 3(11), e1600983. https://doi.org/10.1126/sciadv.1600983

Hoffman P.F., Kaufman A.J., Halverson G.P., Schrag D.P. 1998. A Neoproterozoic Snowball Earth. Science, 281(5381), 1342-1346. https:// doi.org/10.1126/science.281.5381.1342

Hoffman P.F., Li Z.-X. 2009. A palaeogeographic context for Neoproterozoic glaciation. Palaeogeography, Palaeoclimatology, Palaeoecology, 277(3-4), 158172. https://doi.org/10.1016/j.palaeo.2009.03.013

Hoffmann K.-H., Condon D.J., Bowring S.A., Crowley J.L. 2004. U-Pb zircon date from the Neoproterozoic Ghaub Formation, Namibia: Constraints on Marinoan glaciation. Geology, 32(9), 817-820. https://doi. org/10.1130/G20519.1

Hofmann H.J., O’Brien S.J., King A.F. 2008. Ediacaran biota on Bonavista Peninsula, Newfoundland, Canada. Journal of Paleontology, 82(1), 1-36. https://doi.org/10.1666/06-087.1
Holland, H.D. 2006. The oxygenation of the atmosphere and oceans. Philosophical Transactions of the Royal Society A, 361, 903-915.

Horodyski R.J., Knauth L.P. 1994. Life on land in the Precambrian. Science, 263(5146), 494-498. https://doi.org/10.1126/science.263.5146.494

Jahn B., Caby R., Monie P. 2001. The oldest UHP eclogites of the world: age of UHP metamorphism, nature of protoliths and tectonic implications. Chemical Geology, 178(1-4), 143-158. https://doi.org/10.1016/ S0009-2541(01)00264-9

Kendall B., Creaser R.A., Selby D. 2006. Re-Os geochronology of postglacia black shales in Australia: Constraints on the timing of Sturtian" glaciation. Geology, 34(9), 729-732. https://doi.org/10.1130/G22775.1

Kirschvink J.L. (1992). Late Proterozoic low-latitude global glaciation: the snowball Earth. In: Schopf J.W., Klein C. (Eds.). The Proterozoic Biosphere: a multidisciplinary study. Cambridge: Cambridge University Press, p. 51-52.

Knoll A.H. 2014. Paleobiological perspectives on early eukaryotic evolution. Cold Spring Harbor Perspectives in Biology, 6(1), a016121. https://doi. org/10.1101/cshperspect.a016121

Knoll A.H., Bambach R.K. 2000. Directionality in the history of life diffusion from the left wall or repeated scaling of the right? Paleobiology, 26(S.4), 1-14. https://doi.org/10.1017/S0094837300026865

Knoll A.H., Nowak M.A. 2017. The timetable of evolution. Science Advances, 3(5), e1603076. https://doi.org/10.1126/sciadv.1603076

Kröner A., Cordani U. 2003. African, southern Indian and South American cratons were not part of the Rodinia supercontinent: evidence from field relationships and geochronology. Tectonophysics, 375(1-4), 325-352. https://doi.org/10.1016/S0040-1951(03)00344-5

Laflamme, M., Darroch, S.A.F., Tweedt, S.M., Peterson, K.J., Erwin, D.H 2013. The end of the Ediacara biota: Extinction, biotic replacement, or Cheshire Cat? Gondwana Research, 23, 558-573.

Lahr D.J.G., Kosakyan A., Lara E., Mitchell E.A.D., Morais L., PorfirioSousa A.L., Ribeiro G.M., Tice A.K., Pánek T., Kang S., Brown M.W. 2019. Phylogenomics and morphological reconstruction of Arcellinida testate amoebae highlight diversity of microbial eukaryotes in the Neoproterozoic. Current Biology, 29(6), 991-1001.e3. https://doi.org/10.1016/j. cub.2019.01.078

Le Heron D.P., Busfield M.E., Kamona F. 2013. An interglacial on snowball Earth? Dynamic ice behaviour revealed in the Chuos Formation, Namibia. Sedimentology, 60(2), 411-427. https://doi. org/10.1111/j.1365-3091.2012.01346.x

Lenton T.M., Boyle R.A., Poulton S.W., Shields-Zhou G.A., Butterfield N.J. 2014. Co-evolution of eukaryotes and ocean oxygenation in the Neoproterozoic era. Nature Geoscience, 7, 257-265. https://doi. org/10.1038/ngeo2108

Li Z.X., Bogdanova S.V., Collins A.S., Davidson A., De Waele B., Ernst R.E., Fitzsimons I.C.W., Fuck R.A., Gladkochub D.P., Jacobs J., Karlstrom K.E., Lu S., Natapov L.M., Pease V., Pisarevsky S.A., Thrane K., Vernikovsky V. 2008. Assembly, configuration, and break-up history of Rodinia: A synthesis. Precambrian Research, 160(1-2), 179-210. https://doi.org/10.1016/j. precamres.2007.04.021

Liu P., Xiao S., Yin C., Chen S., Zhou C., Li M. 2014. Ediacaran acanthomorphic acritarchs and other microfossils from chert nodules of the upper Doushantuo Formation in the Yangtze Gorges area, South China. Journal of Paleontology, 88(Suppl. 72), 1-139. https://doi. org/10.1666/13-009

Love G.D., Grosjean E., Stalvies C., Fike D.A., Grotzinger J.P., Bradley A.S., Kelly A.E., Bhatia M., Meredith W., Snape C.E., Bowring S.A., Condon D.J., Summons R.E. 2009. Fossil steroids record the appearance of Demospongiae during the Cryogenian period. Nature, 457, 718-721. https://doi.org/10.1038/nature07673

Lyons T.W., Reinhard C.T., Love G.D., Xiao S. 2012. Geobiology of the Proterozoic Eon. In: Knoll A.H., Canfield D.E., Konhauser K.O. (Eds.). Fundamentals of Geobiology. Chichester: John Wiley \& Sons, p. 371-402. https://doi.org/10.1002/9781118280874.ch20

Macdonald F.A., Schmitz M.D., Crowley J.L., Roots C.F., Jones D.S., Maloof A.C., Strauss J.V., Cohen P.A., Johnston D., Schrag D.P. 2010. Calibrating the Cryogenian. Science, 327(5970), 1241-1243. https://doi.org/10.1126/ science. 1183325 
Maloof A.C., Rose C.V., Beach R., Samuels B.M., Calmet C.C., Erwin D.H., Poirier G.R., Yao N., Simons F.J. 2010. Possible animal-body fossils in preMarinoan limestones from South Australia. Nature Geoscience, 3, 653-659. https://doi.org/10.1038/ngeo934

McKeegan K.D., Kudryavtsev A.B., Schopf J.W. 2007. Raman and ion microscopic imagery of graphitic inclusions in apatite from older than 3830 Ma Akilia supracrustal rocks, west Greenland. Geology, 35(7), 591594. https://doi.org/10.1130/G23465A.1

Meert J.G.,Lieberman B.S. 2008. The Neoproterozoic assembly of Gondwana and its relationship to the Ediacaran-Cambrian radiation. Gondwana Research, 14(1-2), 5-21. https://doi.org/10.1016/j.gr.2007.06.007

Meert J.G., Van Der Voo R. 1997. The assembly of Gondwana 800-550 Ma. Journal of Geodynamics, 23(3-4), 223-235. https://doi.org/10.1016/ S0264-3707(96)00046-4

Merdith A.S., Collins A.S., Williams S.E., Pisarevsky S., Foden J.D., Archibald D.B., Blades M.L., Alessio B.L., Armistead S., Plavsa D., Clark C., Müller R.D. 2017. A full-plate global reconstruction of the Neoproterozoic. Gondwana Research, 50, 84-134. https://doi.org/10.1016/j.gr.2017.04.001

Mojzsis S.J., Arrhenius G., McKeegan K.D., Harrison T.M., Nutman A.P., Friend C.R.L. 1996. Evidence for life on Earth before 3,800 million years ago. Nature, 384, 55-59. https://doi.org/10.1038/384055a0

Mojzsis S.J., Harrison T.M., Pidgeon R.T. 2001. Oxygen-isotope evidence from ancient zircons for liquid water at the Earth's surface 4,300 Myr ago. Nature, 409, 178-181. https://doi.org/10.1038/35051557

Morais L., Lahr D.J.G., Rudnitzki I.D., Freitas B.T., Romero G.R., Porter S.M., Knoll A.H., Fairchild T.R. 2019. Insights into vase-shaped microfossil diversity and Neoproterozoic biostratigraphy in light of recent Brazilian discoveries. Journal of Paleontology, 93(4), 612-627. https://doi. org/10.1017/jpa.2019.6

Narbonne G.M., Gehling J.H. 2003. Life after snowball: the oldest complex Ediacaran fossil. Geology, 31(1), 27-30. http://dx.doi. org/10.1130/0091-7613(2003)031<0027:LASTOC>2.0.CO;2

Nutman A.P., Bennett V.C., Friend C.R.L., Van Kranendonk M.J., Chivas A.R. 2016. Rapid emergence of life shown by discovery of 3,700-millionyear-old microbial structures. Nature, 537, 535-538. https://doi. org/10.1038/nature 19355

Och L.M., Shields-Zhou G.A. 2012. The Neoproterozoic oxygenation event: Environmental perturbations and biogeochemical cycling. Earth-Science Reviews, 110(1-4), 26-57. https://doi.org/10.1016/j.earscirev.2011.09.004

Pacheco M.L.A.F., Leme J.M., Machado A.F. 2011. Taphonomic analysis and geometric modeling for the reconstruction of the Ediacaran metazoan Corumbella werneri Hahn et al. 1982 (Tamengo Formation, Corumbá Group, Brazil). Journal of Taphonomy, 9(4), 269-283.

Peterson K.J., Lyons J.B., Nowak K.S., Takacs C.M., Wargo M.J., McPeek M.A. 2004. Estimating metazoan divergence times with a molecular clock. Proceedings of the National Academy of Sciences, 101(17), 6536-6541. https://doi.org/10.1073/pnas.0401670101

Pimentel M.M., Fuck R.A., Jost H., Filho C.F.F., de Araújo S.M. 2000. The basement of the Brasilia fold belt and the Goiás magmatic arc. In: Cordani U.G., Milani E.J., Thomaz-Filho A., Campos D.A. (Eds.). Tectonic evolution of South America: Rio de Janeiro, Brazil. 31st International Geological Congress, p. 195-229.

Planavsky N.J., Rouxel O.J., Bekker A., Lalonde S.V., Konhauser K.O., Reinhard C.T., Lyons T.W. 2010. The evolution of the marine phosphate reservoir. Nature, 467, 1088-1090. https://doi.org/10.1038/ nature 09485

Planavsky N.J., Tarhan L.G., Bellefroid E.J., Evans D.A.D., Reinhard C.T., Love G.D., Lyons T.W. 2015. Late Proterozoic transitions in climate, oxygen, and tectonics, and the rise of complex life. The Paleontological Society Papers, 21, 47-82. https://doi.org/10.1017/S1089332600002965

Pu J.P., Bowring S.A., Ramezani J., Myrow P., Raub T.D., Landing E., Mills A., Hodgin E., Macdonald F.A. 2016. Dodging snowballs: Geochronology of the Gaskiers glaciation and the first appearance of the Ediacaran biota. Geology, 44(11), 955-958. https://doi.org/10.1130/G38284.1

Rivers T. 2008. Assembly and preservation of lower, mid, and upper orogenic crust in the Grenville Province - Implications for the evolution of large hot long-duration orogens. Precambrian Research, 167(3-4), 237-259. https://doi.org/10.1016/j.precamres.2008.08.005
Romero J.A.S., Lafon J.M., Nogueira A.C.R., Soares J.L. 2013. Sr isotope geochemistry and $\mathrm{Pb}-\mathrm{Pb}$ geochronology of the Neoproterozoic cap carbonates, Tangará da Serra, Brazil. International Geology Review, 55(2), 185-203. https://doi.org/10.1080/00206814.2012.692517

Rooney A.D., Macdonald F.A., Strauss J.V., Dudas F.O., Hallmann C., Selby D. 2014. Re-Os geochronology and coupled Os-Sr isotope constraints on the Sturtian snowball Earth. Proceedings of the National Academy of Sciences, 111 (1), 51-56. https://doi.org/10.1073/pnas.1317266110

Rooney A.D., Strauss J.V., Brandon A.D., Macdonald F.A. 2015. A Cryogenian chronology: Two long-lasting synchronous Neoproterozoic glaciations. Geology, 43(5), 459-462. https://doi.org/10.1130/G36511.1

Runnegar B. 1982. A molecular-clock date for the origin of the animal phyla. Lethaia, 15(3), 199-205. https://doi.org/10.1111/j.1502-3931.1982. tb00645.x

Runnegar B. 1986. Molecular palaeontology. Palaeontology, 29(1), 1-24. Available at: <https://www.palass.org/publications/palaeontologyjournal/archive/29/1/article_pp1-24>. Accessed on: Feb 10, 2019.

Santosh M., Maruyama S., Sawaki Y., Meert J.G. 2014. The Cambrian Explosion: Plume-driven birth of the second ecosystem on Earth. Gondwana Research, 25(3), 945-965. https://doi.org/10.1016/j.gr.2013.03.013

Schopf J.W. 1992. Tempo and mode of Proterozoic evolution. In: Schopf J.W., Klein, C. (Eds.). The Proterozoic Biosphere. Cambridge: Cambridge University Press, p. 583-600. https://doi.org/10.1017/CBO9780511601064.015

Schopf J.W. 2006. Fossil evidence of Archaean life. Philosophical Transactions of the Royal Society B: Biological Sciences, 361(1470), 869-885. https://doi. org/10.1098/rstb.2006.1834

Seilacher A. 1989. Vendozoa: Organismic construction in the Proterozoic biosphere. Lethaia, 22(3), 229-239. https://doi. org/10.1111/j.1502-3931.1989.tb01332.x

Seilacher A. 1992. Vendobionta and Psammocorallia: lost constructions of Precambrian evolution. Geological Society of London, Special Publication, 149, 607-613

Seilacher A. 1999. Biomat-related lifestyles in the Precambrian. Palaios, 14(1), 86. https://doi.org/10.2307/3515363

Seilacher A. 2007. The nature of vendobionts. In: Vickers-Rich P., Komarower P. (Eds.). The Rise and Fall of the Ediacaran Biota. London, Geological Society, Special Publication, v. 286, p. 387-397.

Shen B., Dong L., Xiao S., Kowalewski M. 2008. The Avalon explosion: evolution of Ediacara morphospace. Science, 319(5859), 81-84. https://doi. org/10.1126/science.1150279

Spence G.H., Le Heron D.P., Fairchild I.J. 2016. Sedimentological perspectives on climatic, atmospheric and environmental change in the Neoproterozoic Era. Sedimentology, 63(2), 253-306. https://doi. org/10.1111/sed.12261

Sperling E.A., Frieder C.A., Raman A.V., Girguis P.R., Levin L.A., Knoll A.H. 2013. Oxygen, ecology, and the Cambrian radiation of animals. Proceedings of the National Academy of Sciences, 110(33), 13446-13451. https://doi.org/10.1073/pnas.1312778110

Sperling E.A., Wolock C.J., Morgan A.S., Gill B.C., Kunzmann M., Halverson G.P., Macdonald F.A., Knoll A.H., Johnston D.T. 2015. Statistical analysis of iron geochemical data suggests limited late Proterozoic oxygenation. Nature, 523, 451-454. https://doi.org/10.1038/nature14589

Squire R., Campbell I., Allen C., Wilson C. 2006. Did the Transgondwanan Supermountain trigger the explosive radiation of animals on Earth? Earth and Planetary Science Letters, 250(1-2), 116-133. https://doi.org/10.1016/j. eps1.2006.07.032

Stern R.J. 1994. ARC Assembly and continental collision in the Neoproterozoic East African Orogen: implications for the consolidation of Gondwanaland. Annual Review of Earth and Planetary Sciences, 22, 319-351. https://doi.org/10.1146/annurev.ea.22.050194.001535

Tang F., Yin C., Bengtson S., Liu P., Wang Z., Gao L. 2008. Octoradiate spiral organisms in the Ediacaran of South China. Acta Geologica Sinica, 82(1), 27 34. https://doi.org/10.1111/j.1755-6724.2008.tb00321.x

Trindade R., D’Agrella Filho M., Epof I., Brito Neves B. 2006. Paleomagnetism of Early Cambrian Itabaiana mafic dikes (NE Brazil) and the final assembly of Gondwana. Earth and Planetary Science Letters, 244(12), 361-377. https://doi.org/10.1016/j.epsl.2005.12.039 
Tsujimori T., Sisson V., Liou J., Harlow G., Sorensen S. 2006. Very-lowtemperature record of the subduction process: A review of worldwide lawsonite eclogites. Lithos, 92(3-4), 609-624. https://doi.org/10.1016/j. lithos.2006.03.054

ValleyJ.W.,PeckW.H., KingE.M.,WildeS.A.2002.AcoolearlyEarth. Geology, 30(4),351-354.https://doi.org/10.1130/0091-7613(2002)030<0351:AC $\mathrm{EE}>2.0 . \mathrm{CO} ; 2$

Van Hunen J., Moyen J.-F. 2012. Archean subduction: fact or fiction? Annual Review of Earth and Planetary Sciences, 40, 195-219. https://doi. org/10.1146/annurev-earth-042711-105255

Van Iten H., Leme J.M., Pacheco M.L.A.F., Simões M.G., Fairchild T.R. Rodrigues F., Galante D., Boggiani P.C., Marques A.C. 2016. Origin and Early Diversification of Phylum Cnidaria: Key Macrofossils from the Ediacaran System of North and South America. In: Dubinsky S.G.Z. (Ed.). The Cnidaria, Past, Present and Future. Switzerland: Springer International Publishing, p. 31-40. https://doi.org/10.1007/978-3-319-31305-4_3

Van Iten H., Marques A.C., Leme J.M., Pacheco M.L.A.F., Simões M.G. 2014. Origin and early diversification of the phylum Cnidaria Verrill: major developments in the analysis of the taxon's Proterozoic-Cambrian history. Palaeontology, 57(4), 677-690. https://doi.org/10.1111/pala.12116

Veizer J. 1989. Strontium isotopes in seawater through time. Annual Review of Earth and Planetary Sciences, 17, 141-167. https://doi.org/10.1146/ annurev.ea.17.050189.001041

Wan B., Yuan X., Chen Z., Guan C., Pang K., Tang Q. Xiao S. 2016. Systematic description of putative animal fossils from the early Ediacaran Lantian Formation of South China. Palaeontology, 59(4), 515-532.

Warren L.V., Pacheco M.L.A.F., Fairchild T.R., Simões M.G., Riccomini C., Boggiani P.C, Cáceres A.A. 2012. The dawn of animal skeletogenesis: ultrastructural analysis of the Ediacaran metazoan Corumbella werneri. Geology, 40(8), 691-694.
Wood R., Liu A.G., Bowyer F., Wilby P.R., Dunn F.S., Kenchington C.G., Hoyal Cuthill J.F., Mitchell E.G., Penny A. 2019. Integrated records of environmental change and evolution challenge the Cambrian Explosion. Nature Ecology and Evolution, 3, 528-538. https://doi.org/10.1038/ s41559-019-0821-6

Xiao S., Muscente A. D., Chen L., Zhou C., Schiffbauer J.D., Wood A.D. Polys N.F., Yuan X. 2014. The Weng'an biota and the Ediacaran radiation of multicellular eukaryotes. National Science Review, 1(4), 498-520. https:// doi.org/10.1093/nsr/nwu061

Xiao S., Yuan X., Steiner M., Knoll A.H. 2002. Macroscopic carbonaceous compressions in a terminal Proterozoic shale: A systematic reassessment of the Miaohe biota, south China. Journal of Paleontology, 76(2), 347-376. https://doi.org/10.1017/S0022336000041743

Yin Z., Zhu M., Davidson E.H., Bottjer D.J., Zhao F., Tafforeau P. 2015. Sponge grade body fossil with cellular resolution dating $60 \mathrm{Myr}$ before the Cambrian. Proceedings of the National Academy of Sciences, 112(12), E1453-E1460. https://doi.org/10.1073/pnas.1414577112

Yuan X., Chen Z., Xiao S., Zhou C., Hua H. 2011. An early Ediacaran assemblage of macroscopic and morphologically differentiated eukaryotes. Nature, 470, 390-393. https://doi.org/10.1038/nature09810

Zhang K., Zhu X., Wood R.A., Shi Y., Gao Z., Poulton S.W. 2018. Oxygenation of the Mesoproterozoic ocean and the evolution of complex eukaryotes. Nature Geoscience, 11,345-350. https://doi.org/10.1038/s41561-018-0111-y

Zhang S., Jiang G., Han Y. 2008. The age of the Nantuo Formation and Nantuo glaciation in South China. Terra Nova, 20(4), 289-294. https://doi. org/10.1111/j.1365-3121.2008.00819.x

Zhou, C., Li, X., Xiao, S., Lan, Z., Ouyang, Q., Guan, C., Chen, Z. 2017. A new SIMS zircon U-Pb date from the Ediacaran Doushantuo Formation: age constraint on the Weng'an biota. Geological Magazine, 154(6), 11931201. https://doi.org/10.1017/S0016756816001175 